\title{
2-Azetidinones as Precursors of Pincer Ligands: Preparation, Struc- ture, and Spectroscopic Properties of CC'N-Osmium Complexes
}

\author{
Luis Casarrubios, ${ }^{\ddagger}$ Miguel A. Esteruelas, ${ }^{+*}$ Carmen Larramona, ${ }^{\dagger}$ Jaime G. Muntaner,${ }^{\dagger}$ Enrique Oña- \\ te, ${ }^{\dagger}$ and Miguel A. Sierra ${ }^{\ddagger}$ \\ †Departamento de Química Orgánica, Facultad de Ciencias Químicas, Centro de Innovación en Química Avanzada (ORFEO- \\ CINQA), Universidad Complutense, 28040 Madrid, Spain \\ †Departamento de Química Inorgánica, Instituto de Síntesis Química y Catálisis Homogénea (ISQCH), Centro de Innovación \\ en Química Avanzada (ORFEO-CINQA), Universidad de Zaragoza-CSIC, 50009 Zaragoza, Spain
}

\begin{abstract}
A metal-promoted degradation of 2-azetidinones to afford $\mathrm{CC}^{\prime} \mathrm{N}$-pincer ligands is reported. The hexahydride complex $\mathrm{OsH}_{6}\left(\mathrm{P}^{\mathrm{i}} \mathrm{Pr}_{3}\right)_{2} \quad$ (1) reacts with ( \pm )-cis-1-(4-methoxyphenyl)-3-phenoxy-4-(pyridin-2-yl)azetidi-2-one (I), ( \pm )-cis-1-(4methoxyphenyl)-3-phenoxy-4-(isoquinolin-2-yl)azetidi-2-one (II), and ( \pm )-cis-1-(4-methoxyphenyl)-3-phenoxy-4-(quinolin-2yl)azetidi-2-one (III) to give the respective $\mathrm{OsH}_{2}\left(\mathrm{P}^{\mathrm{i}} \mathrm{Pr}_{3}\right)_{2}\left(\mathrm{CC} \mathrm{C}^{\prime} \mathrm{N}\right)$ (2-4) complexes, which add $\mathrm{HBF}_{4} \cdot \mathrm{OEt}_{2}$ to yield $\left[\mathrm{OsH}_{2}\left(\mathrm{P}^{\mathrm{i}} \mathrm{Pr}_{3}\right)_{2}\left(\mathrm{CC}^{\prime \prime} \mathrm{N}\right)\right] \mathrm{BF}_{4}(5-7)$. These salts are the result of the addition of the proton of the acid to the dianionic $\mathrm{CC}^{\prime} \mathrm{N}$-pincer ligand. The hydride ligands of these compounds undergo quantum mechanical exchange coupling, which has been experimentally quantified according to a two dimensional harmonic oscillator model, where $J_{\mathrm{ex}}$ is determined by the separation between the hydrides, their hard sphere radius, and a $v$ parameter describing the H-M-H vibrational wag mode allowing the movement along the $\mathrm{H}-\mathrm{H}$ vector. The comparison of the results reveals that the phenomenon is particularly intense for 5-7. Furthermore, in these compounds, the separation between the hydrides is about $0.1 \AA$ shorter than in the respective neutral species $\mathbf{2 - 4}$ whereas the hydride hard sphere radius increases about $10 \%$, and the $v$ value decreases about $20 \%$.
\end{abstract}

\section{INTRODUCTION}

The C-H, C-N, and C-C cleavages are among the most relevant metal-mediated $\sigma$-bond activation processes. The $\mathrm{C}-\mathrm{H}$ bond activation is a classical issue in organometallics because of its connection with the functionalization of nonactivated organic molecules. ${ }^{1}$ The rupture of $\mathrm{C}-\mathrm{N}$ bonds ${ }^{2}$ is of importance as a necessary step in the hydrodenitrogenation of petroleum, ${ }^{3}$ shows interesting applications in organic synthesis, ${ }^{4}$ and is playing a main role in the understanding of the degradation processes of metal-catalysts based on $\mathrm{N}$ heterocyclic carbene ligands. ${ }^{5}$ The metal-mediated rupture of $\mathrm{C}-\mathrm{C}$ bonds $^{6}$ is much less frequent than the cleavages of $\mathrm{C}-\mathrm{H}$ and $\mathrm{C}-\mathrm{N}$ bonds. The low polarity and the characteristic directionality of the $\sigma$-orbitals provide both thermodynamic and kinetic obstacles to $\mathrm{C}-\mathrm{C}$ bond activation. Thus, its general applicability in synthetically useful transformations remains limited. ${ }^{7}$ Two strategies are being used to facilitate the $\mathrm{C}-\mathrm{C}$ bond cleavage. One is to increase the energy state of the starting organic molecule by employing strained rings ${ }^{8}$ and other is to decrease the strength of the $\mathrm{C}-\mathrm{C}$ bond by increasing its polarity. ${ }^{9}$ It has been also shown processes of $\mathrm{C}-\mathrm{C}$ rupture, which are facilitated by previous $\mathrm{C}-\mathrm{H}$ bond activation. ${ }^{10}$ The sequential cleavage of several different $\sigma$-bonds is part of the degradation processes of organic molecules. However, its rational use may be ideal for accessing complex molecular architectures.

The saturated hexahidride complex $\mathrm{OsH}_{6}\left(\mathrm{P}^{\mathrm{i}} \mathrm{Pr}_{3}\right)_{2}$ has proven activate $\mathrm{C}-\mathrm{H}$ bonds ${ }^{11}$ of a wide range of organic molecules, as well as a few $\mathrm{N}-\mathrm{H}^{12}$ and $\mathrm{N}-\mathrm{C}^{13}$ bonds. In agreement with the ability of this compound to break N-H bonds, it reacts with 4(2-pyridyl)- and 4-(2-quinolyl)-2-azetidinones to form osmatrinems, resulting from the $\mathrm{N}-\mathrm{H}$ bond cleavage of the $\beta$-lactam and the coordination of both nitrogen atoms to the osmium center. ${ }^{14}$ The replacement of the NH-hydrogen by an aryl group protects the amidic nitrogen atom against the metal center, which is then directed towards the $\mathrm{C} 4-\mathrm{H}$ bond of the four membered ring. ${ }^{15}$ The addition of this bond to the metal center allows the active participation of an osmium lone pair in the B-type $\beta$-lactam fragmentation, ${ }^{16}$ which becomes thermally accessible through a stepwise process. Thus, the reaction of the hexahydride complex with $( \pm)-c i s-1-(4-$ methoxyphenyl)-3-methoxy-4-(pyridine-2-yl)azetidi-2-one affords $\mathrm{OsH}_{3}\left\{\kappa^{2}-\mathrm{C}, \mathrm{N}-[\mathrm{py}-2-\mathrm{CH}=\mathrm{COMe}]\right\}\left(\mathrm{P}^{\mathrm{i}} \mathrm{Pr}_{3}\right)_{2}$, after the expansion of the resulting four-membered heterometalaring ${ }^{17}$ (Scheme 1). 


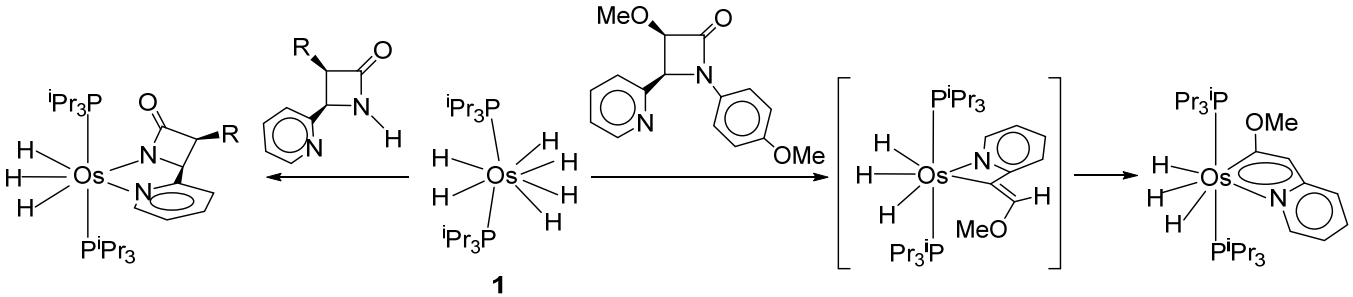

Scheme 1

Because is the $\mathrm{M}-\mathrm{C}$ bond strength that dominates in the determination of the position of the metal-mediated $\mathrm{C}-\mathrm{H}$ bond activation equilibrium, not the $\mathrm{C}-\mathrm{H}$ bond strength, the arene$\mathrm{CH}$ bond activation is thermodynamically favored with regard to the alkane- $\mathrm{CH}$ bond activation in spite of that an arene- $\mathrm{CH}$ bond is stronger than an alkene- $\mathrm{CH}$ bond. The arene-CH bond activation is also kinetically favored as a consequence of its prior $\eta^{2}$-arene coordination. ${ }^{1 \mathrm{le}, 18}$ This basic principle of organometallics prompt us to replace the methoxy substituent at 3position of the lactamic four-membered ring by a phenoxy group and to perform the reactions of the hexahydride complex with the N-aryl-2-azetidinones shown in Chart 1, in order to build novel $\left(\mathrm{CC}^{\prime} \mathrm{N}\right)$ Os-pincer complexes. Although the reactions would proceed by a different pathway, in view of the kinetic preference of the arene $\mathrm{C}-\mathrm{H}$ bond activation, the resulting products should be more stable and robust.

Pincer compounds are having tremendous impact in the modern chemistry of transition metal, in particular those of platinum group. ${ }^{19}$ The mer-disposition of the donor atoms of the ligands allows to design complexes with applications ranging from catalysis ${ }^{20}$ and medicine ${ }^{21}$ to material science. ${ }^{22}$ Furthermore, because complexes with these ligands are generally very robust, they have been used as intermediates in synthetic procedures requiring drastic experimental conditions. Thus, for instance, we have recently shown that dihydride-osmium(IV) complexes of formula $\mathrm{OsH}_{2}(\mathrm{CCC})\left(\mathrm{P}^{\mathrm{i}} \mathrm{Pr}_{3}\right)_{2}$ are the key species for the preparation of homoleptic and heteroleptic osmium(II) compounds, containing two pincer ligands, which are phosporescent emitters in the blue-green region. ${ }^{22 \mathrm{~b}}$ Compared with other platinum group metals, the osmium complexes are significantly less developed. They are based on neutral ${ }^{23}$ CCC-,${ }^{22}$ NNX- $(\mathrm{X}=\mathrm{C}, \mathrm{N}, \mathrm{S}),{ }^{24} \mathrm{NCN}-,{ }^{21 \mathrm{c}}$ and PXP- $(\mathrm{X}=\mathrm{C}, \mathrm{N})^{25}$ monoanionic, and $\mathrm{CNX}-(\mathrm{X}=\mathrm{C}, \mathrm{O}),{ }^{26}$ and $\mathrm{ONO}^{27}$-dianionic ligands.

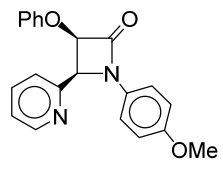

(I)

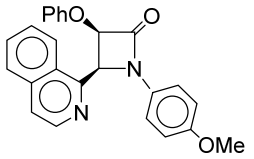

(II)

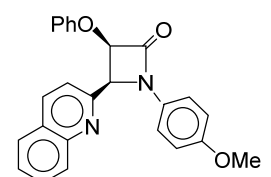

(III)
Chart 1

This paper describes the preparation and structural characterization of osmium-dihydride complexes stabilized by the first $\mathrm{CC}^{\prime} \mathrm{N}$-dianionic and $\mathrm{CC}^{\prime \prime} \mathrm{N}$-monanionic pincer ligands in the osmium chemistry. These ligands, which can not be generated by direct coordination of any organic fragment, result from two $\mathrm{C}-\mathrm{H}$ bond activations and the breakage of parallel $\mathrm{C}-\mathrm{N}$ and $\mathrm{C}-\mathrm{C}$ bonds in a type-B-rupture of 2-azetidinones. In addition, an spectacular quantum mechanical exchange coupling undergoing by the hydride ligands is quantified through a two dimensional harmonic oscillator model.

\section{RESULTS AND DISCUSSION}

1 Dianionic ligands. In agreement with the thermodynamic and kinetic preference of the arene- $\mathrm{CH}$ bond activation over the alkane-CH bond activation, the replacement of the metoxy substituent by a phenoxy group allows that the degradation of the azetidinones gives rise to dianionic $\mathrm{CC}^{\prime} \mathrm{N}$-pincer ligands, as a result of the additional ortho- $\mathrm{CH}$ bond activation of the phenoxy group. Thus, the treatment of toluene solutions of $\mathrm{OsH}_{6}\left(\mathrm{P}^{\mathrm{i}} \mathrm{Pr}_{3}\right)_{2}$ (1) with 1.0 equiv of $\mathbf{I}, \mathbf{I I}$, and $\mathbf{I I I}$, for $6 \mathrm{~h}$, under reflux leads to the pincer-osmium(IV)-dihydride complexes $\mathbf{2}$, $\mathbf{3}$, and 4, respectively, which were isolated as a yellow solid (2) or red solids $(3,4)$ in $60-70 \%$ yield, according to Scheme 2 .

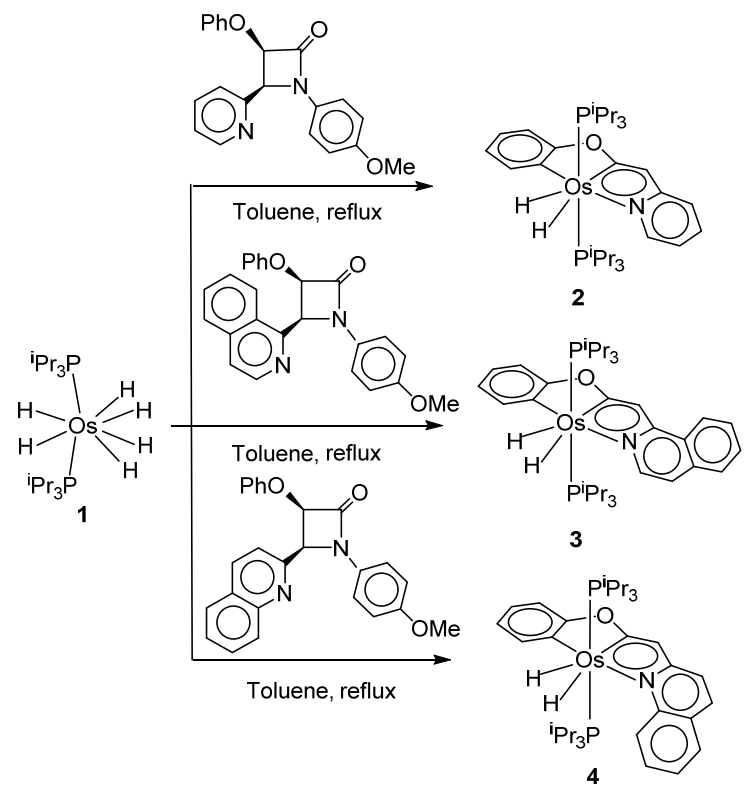

Scheme 2

The similarity between the formation of 2-4 and the reaction of 1 with ( \pm )-cis-1-(4-methoxyphenyl)-3-methoxy-4-(pyridine2-yl)azetidi-2-one is only formal. In this context, it should be noted that the activation of the ortho- $\mathrm{CH}$ bond of the phenoxy group, which is kinetically preferred, should favor the direct activation of $\mathrm{C} 3-\mathrm{H}$. The activation of the latter instead of C4$\mathrm{H}$ may change the mechanism of the fragmentation of the four membered ring.

Complexes $\mathbf{2}$ and $\mathbf{4}$ were characterized by X-ray diffraction analysis. The structures prove the formation of the pincer ligands. Figure 1 shows a drawing of the pyridyl derivative 2 . As expected for the pincer coordination, the donor atoms of 
the tridentate ligand are mer disposed with the pyridyl and aryl groups located pseudo trans $\left(\mathrm{N}(1)-\mathrm{Os}-\mathrm{C}(1)=149.06(11)^{\circ}\right)$. Thus, the coordination geometry around the metal center can be rationalized as a distorted pentagonal bipyramid with axial phosphines $\left(\mathrm{P}(1)-\mathrm{Os}-\mathrm{P}(2)=160.2(3)^{\circ}\right)$ and the hydride ligands, separated by 1.62(4) $\AA$, lying in the equatorial plane along with the pincer. The Os-C(1) bond length of 2.119(3) $\AA$ is in agreement with the Os-aryl distances found in other fivemembered osmacycles resulting from ortho-metalation reactions ${ }^{11,28}$ whereas the Os-C(7), C(7)-C(8), C(8)-C(9), and Os$\mathrm{N}(1)$ distances of 2.057(3), 1.360(4), 1.411(4), and 2.154(3) $\AA$, respectively, compare well with the related parameters of $\mathrm{OsH}_{3}\left\{\kappa^{2}-\mathrm{C}, \mathrm{N}-[\mathrm{py}-2-\mathrm{CH}=\mathrm{CR}]\right\}\left(\mathrm{P}^{\mathrm{i}} \mathrm{Pr}_{3}\right)_{2}\left(\mathrm{R}=\mathrm{H}^{29}, \mathrm{OMe}^{17}\right)$. The structure of 4 (Figure 2) resembles that of 2 with the quinolyl group occupying the position of the pyridyl and $\mathrm{N}(1)-\mathrm{Os}-\mathrm{C}(1)$ and $\mathrm{P}(1)-\mathrm{Os}-\mathrm{P}(2)$ angles of $149.4(2)^{\circ}$, and $161.07(6)^{\circ}$, respectively. The Os-C(1), Os-C(7), C(7)-C(8), C(8)-C(9) and Os$\mathrm{N}(1)$ bond lengths of 2.107(6), 2.038(6), 1.372(8), 1.392(8), and 2.244(5) $\AA$, respectively, are statically identical to those of 2 .

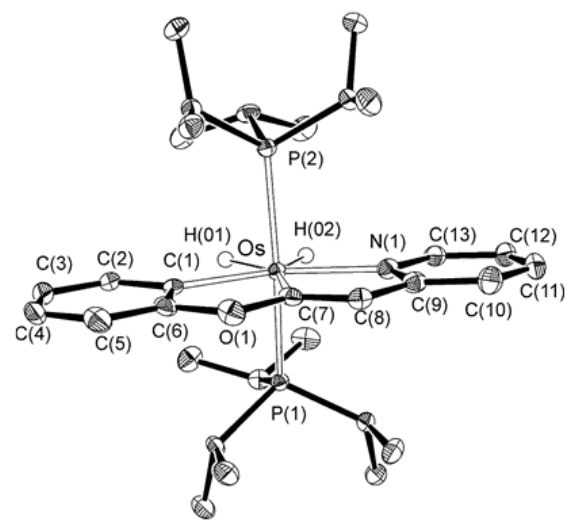

Figure 1. ORTEP diagram of complex 2 (50\% probability ellipsoids). Selected bond lengths $(\AA)$ and angles (deg): Os$\mathrm{C}(1)=2.119(3)$, Os-C(7) $=2.057(3), \mathrm{C}(7)-\mathrm{C}(8)=1.360(4)$, $\mathrm{C}(8)-\mathrm{C}(9)=1.411(4)$, Os- $\mathrm{N}(1)=2.154(3)$, Os- $\mathrm{P}(1)=$ 2.3588(8), Os- $\mathrm{P}(2)=2.3747(8), \mathrm{P}(1)-\mathrm{Os}-\mathrm{P}(2)=160.2(3)$, $\mathrm{C}(1)-\mathrm{Os}-\mathrm{C}(7)=74.83(12), \mathrm{N}(1)-\mathrm{Os}-\mathrm{C}(7)=74.22(11)$, Os$\mathrm{C}(7)-\mathrm{C}(8)=121.1(2), \mathrm{N}(1)-$ Os-C $(1)=149.05(11)$.

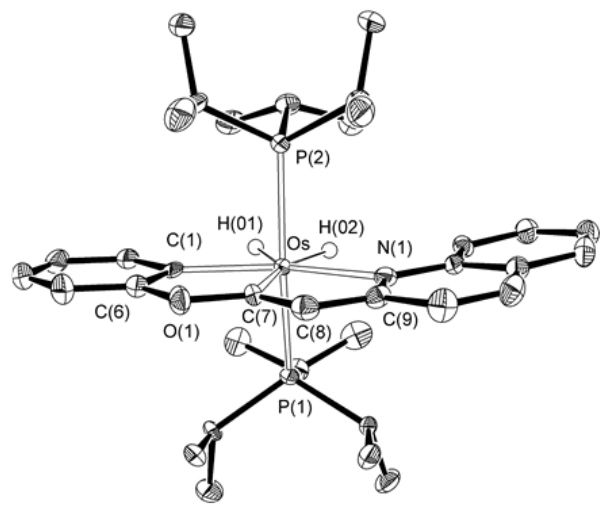

Figure 2. ORTEP diagram of complex 4 (50\% probability ellipsoids). Selected bon lengths $(\AA)$ and angles (deg): Os$\mathrm{C}(1)=2.107(6)$, Os-C(7) $=2.038(6), \mathrm{C}(7)-\mathrm{C}(8)=1.372(8)$, $\mathrm{C}(8)-\mathrm{C}(9)=1.392(8)$, Os- $\mathrm{N}(1)=2.244(5)$, Os- $\mathrm{P}(1)=$ 2.3743(15), Os- $\mathrm{P}(2)=2.3689(14)$, $\mathrm{P}(1)$-Os- $\mathrm{P}(2)=161.07(6)$, $\mathrm{N}(1)-O s-\mathrm{C}(1)=149.4(2), \mathrm{C}(1)-\mathrm{Os}-\mathrm{C}(7)=75.1(2), \mathrm{N}(1)$-Os$\mathrm{C}(7)=74.3(2)$, Os-C(7)-C(8) = 121.5(4).
The ${ }^{1} \mathrm{H},{ }^{13} \mathrm{C}\left\{{ }^{1} \mathrm{H}\right\}$ and ${ }^{31} \mathrm{P}\left\{{ }^{1} \mathrm{H}\right\}$ NMR spectra of $\mathbf{2 - 4}$, in toluene, are consistent with the structures shown in Figures 1 and 2. As expected for inequivalent hydrides, the ${ }^{1} \mathrm{H}$ NMR spectra contain two high field resonances between -3 and $-8 \mathrm{ppm}$. In the ${ }^{13} \mathrm{C}\left\{{ }^{1} \mathrm{H}\right\}$ NMR spectra, the metalated central carbon atom of the pincers displays a low field resonance between 257 and $248 \mathrm{ppm}$, suggesting that in these compounds there is a significant electron delocalization in the five-membered azametalacycle, in agreement with $\mathrm{OsH}_{3}\left\{\kappa^{2}-\mathrm{C}, \mathrm{N}-[\mathrm{py}-2-\right.$ $\mathrm{CH}=\mathrm{CR}]\}\left(\mathrm{P}^{\mathrm{i}} \mathrm{Pr}_{3}\right)_{2}$ and related compounds. ${ }^{30}$ The signal corresponding to the metalated carbon atom of the aryl group is observed at about $137 \mathrm{ppm}$. The ${ }^{31} \mathrm{P}\left\{{ }^{1} \mathrm{H}\right\}$ spectra show a singlet between 4 and $8 \mathrm{ppm}$ in accordance with the equivalence of the phosphines.

The pyridyl complex 2 shows interesting photophysical properties. The absorption spectrum of a $2 \times 10^{-4} \mathrm{M}$ toluene solution of this compound, at $298 \mathrm{~K}$, exhibits two main bands at the visible region: an intense absorption centered at $350 \mathrm{~nm}$ and a less intense band centered at $466 \mathrm{~nm}$. In agreement with these absorptions, the calculated spectrum by means of timedependent density functional theory (TD-DFT) under vacuum shows higher energy absorptions at $321(0.274) \mathrm{nm}$ and 367 $(0.0144) \mathrm{nm}$ and a lower energy absorptions at $441(0.0148)$ $\mathrm{nm}$. The higher energy band is the result of the combination of two one-electron promotions from the HOMO-1 to the LUMO and from the HOMO to the LUMO+1 (74\% and $24 \%)$ whereas the lower energy band is mainly a HOMO to LUMO transition $(98 \%)$. The high energy region of the spectra is dominated by interligand charge transfer transitions with remarkable $\pi-\pi^{*}$ character, whereas the low energy absorption mainly involves metal-to-ligand charge transfer processes. In addition, complex 2 is emissive upon photoexcitation in the solid state at room temperature and in toluene solution at room temperature and a $77 \mathrm{~K}$. The lifetimes are 1.1, 2.0 and $6.6 \eta \mathrm{s}$, respectively, whereas the quantum yield in the solid state is 0.06 . This dihydride is yellow emissive in the solid state $(571 \mathrm{~nm})$ and in toluene $(562 \mathrm{~nm})$ at room temperature and green $(540 \mathrm{~nm})$ in toluene at $77 \mathrm{~K}$. The computed difference in energy between the optimized triplet excited state and the singlet ground state with the same geometry $(598 \mathrm{~nm})$ is consistent with the experimental emission wavelengths, suggesting that the observed luminescence is phosphorescence resulting of the emission from the triplet state of lower energy.

2 Monoanionic ligands. The electron delocalization in the azametalacycle exacerbates the nucleophilicity of its $\mathrm{C}-\mathrm{H}$ carbon atom $(\mathrm{C}(8)$ in Figures 1 and 2$)$, which becomes a Brønsted base stronger than the metal center and the hydride ligands. As a result, the addition of 1.0 equiv of $\mathrm{HBF}_{4} \cdot \mathrm{OEt}_{2}$ to diethyl ether solutions of $\mathbf{2}, \mathbf{3}$, and $\mathbf{4}$, at room temperature, produces its selective protonation to afford monoanionic $\mathrm{CC}^{\prime \prime} \mathrm{N}$-pincer ligands, which stabilize the cationic dihydrideosmium(IV) derivatives 5, 6 and 7, respectively (Scheme 3). These salts were isolated as white solids in almost quantitative (89-96\%) yield.

Complex $\mathbf{5}$ was characterized by X-ray diffraction analysis. Figure 3 shows a view of the cation of the salt. The coordination geometry around the osmium atom is similar to that of 2 with $\mathrm{N}(1)-\mathrm{Os}-\mathrm{C}(1)$ and $\mathrm{P}(1)-\mathrm{Os}-\mathrm{P}(1 \mathrm{~A})$ angles of $151.08(18)^{\circ}$ and $157.07(4)^{\circ}$ respectively. The most noticeable differences between both structures are observed in the sequence Os- $\mathrm{C}(7)$ $\mathrm{C}(8)-\mathrm{C}(9)$. While the Os-C(7) bond length (1.973(5) $\AA$ ) shortens about $0.08 \AA$, the $\mathrm{C}(7)-\mathrm{C}(8)$ and $\mathrm{C}(8)-\mathrm{C}(9)$ distances 
(1.501(7) and 1.493(7) Å, respectively) lengthen between 0.09 and $0.14 \AA$ with regard to 2 . The Os- $\mathrm{C}(1)$ and $\mathrm{Os}-\mathrm{N}(1)$ bond lengths of 2.104(5) and 2.164(4) $\AA$, respectively, are however statically identical to those of 2 . The Os-C(7) bond length is consistent with an Os-Fischer-type carbene separation ${ }^{31}$ whereas the $\mathrm{C}(7)-\mathrm{C}(8)$ and $\mathrm{C}(8)-\mathrm{C}(9)$ distances are in accordance with $\mathrm{C}\left(\mathrm{sp}^{3}\right)-\mathrm{C}\left(\mathrm{sp}^{2}\right)$ bonds.

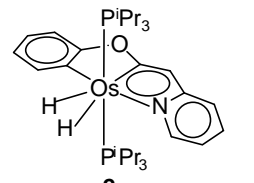

2

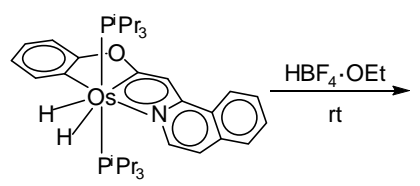

3

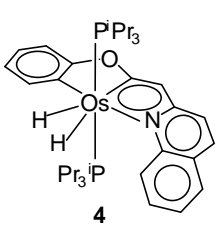

4

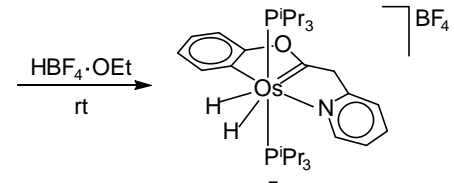

5

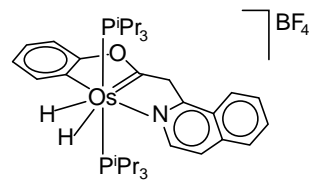

6

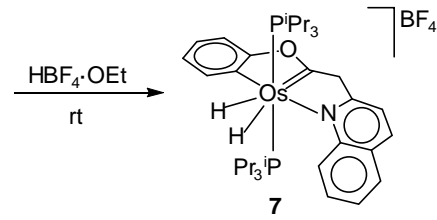

Scheme 3

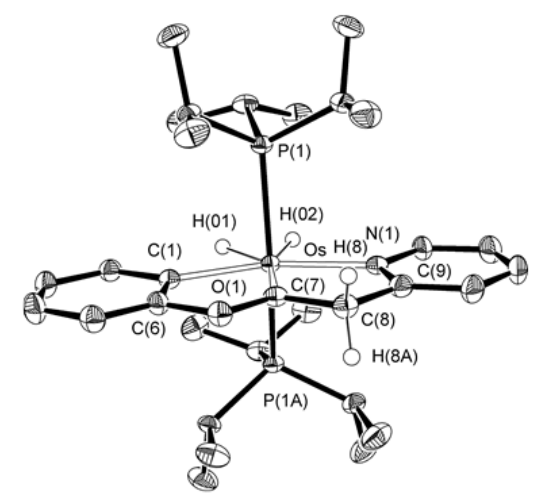

Figure 3. ORTEP diagram of the cation of complex $5(50 \%$ probability ellipsoids). Selected bond lengths $(\AA)$ and angles (deg): Os-C $(1)=2.104(5)$, Os- $\mathrm{C}(7)=1.973(5), \mathrm{C}(7)-\mathrm{C}(8)=$ 1.501(7), $\mathrm{C}(8)-\mathrm{C}(9)=1.493(7)$, Os- $\mathrm{N}(1)=2.164(4)$, Os- $\mathrm{P}(1)=$ $2.4090(9), \quad \mathrm{P}(1)-\mathrm{Os}-\mathrm{P}(2)=157.07(4), \quad \mathrm{C}(1)-\mathrm{Os}-\mathrm{N}(1)=$ 151.08(18), C(7)-Os-N(1) = 76.28(17).

The ${ }^{1} \mathrm{H},{ }^{13} \mathrm{C}\left\{{ }^{1} \mathrm{H}\right\}$ and ${ }^{31} \mathrm{P}\left\{{ }^{1} \mathrm{H}\right\}$ NMR spectra of 5-7, in dichloromethane- $d_{2}$, are consistent with the structure shown in Figure 3. The ${ }^{1} \mathrm{H}$ NMR spectra at $183 \mathrm{~K}$ contain an $\mathrm{ABX}_{2}$ spin system, centered between -3 and $-5 \mathrm{ppm}$, in agreement with two inequivalent hydride ligands. In the ${ }^{13} \mathrm{C}\left\{{ }^{1} \mathrm{H}\right\}$ NMR spectra, the resonance corresponding to the metalated central carbon atom of the pincers is observed at about $300 \mathrm{ppm}$, shifted about $40 \mathrm{ppm}$ to lower field with regard to those of their neutral precursors, whereas the signal due to the metalated carbon atom of the aryl group appears at about $168 \mathrm{ppm}$. The ${ }^{31} \mathrm{P}\left\{{ }^{1} \mathrm{H}\right\}$
NMR spectra show between 15 and 20 ppm a singlet, as expected for equivalent phosphines.

3. Quantum mechanical exchange coupling. The ${ }^{1} \mathrm{H}$ NMR spectra of complexes 2-7 in the high field region are temperature dependent, increasing the observed $\mathrm{H}-\mathrm{H}$ coupling constant $\left(J_{\text {obs }}\right)$ as the temperature increases. Figure 4 shows the spectrum of 4 as a function of the temperature between 183 and $273 \mathrm{~K}$. The increment $\left(\Delta J_{\text {obs }}=J_{\text {obs }}^{273}-J_{\text {obs }}^{183}\right)$ depends upon the nature of the heterocyclic substituent of the starting azetidinone and the charge of the complexes. Thus, the values diminish in the sequence quinolyl $(\mathbf{7 , 4})>$ pyridyl $(\mathbf{5 , 2}) \geq$ isoquinolyl $(6,3)$ and are higher for the salts 7-5 than for the respective neutral species 4-2 (Table 1 ).

The large values of $J_{\text {obs }}$ and their dependence with the temperature can be readily explained in terms of quantum mechanical exchanges coupling ${ }^{32}$ between the hydride ligands. The phenomenon involves the exchange of the hydrogen nuclei, which occurs by tunneling through a low barrier between the two sides of the double-well potential. ${ }^{33}$

The vibrational motion of the two hydrides must be considered as a whole. This finite overlap gives rise to both a symmetric and an antisymmetric combination of the two single-particle wave functions, which differ in energy by $2 J_{\text {ex }}$. This amount is related with $J_{\text {obs }}$ by means of eq 1 . Constant $J_{\text {mag }}$ is the portion of $J_{\text {obs }}$ due to the Fermi contact interaction, i.e., independent from the temperature and its sign may vary from compound to compound.

$$
J_{\text {obs }}=J_{\text {mag }}-2 J_{\text {ex }}
$$

The term $J_{\text {ex }}$ represents the quantum mechanical exchange coupling between the hydrides, is inherently negative, and can be determined by eq 2 , according to a two dimensional harmonic oscillator model. ${ }^{34}$

$$
J_{\text {ex }}=\left(-\hbar a / 2 m \pi^{2} \lambda \delta^{2}\right) \exp \left\{\left(a^{2}+\lambda^{2}\right) / 2 \delta^{2}\right\}
$$

where

$$
\delta^{2}=\left[\mathrm{h} / 4 \pi^{2} \mathrm{~m} v\right] \operatorname{coth}[\mathrm{h} v / 2 \mathrm{kT}]
$$

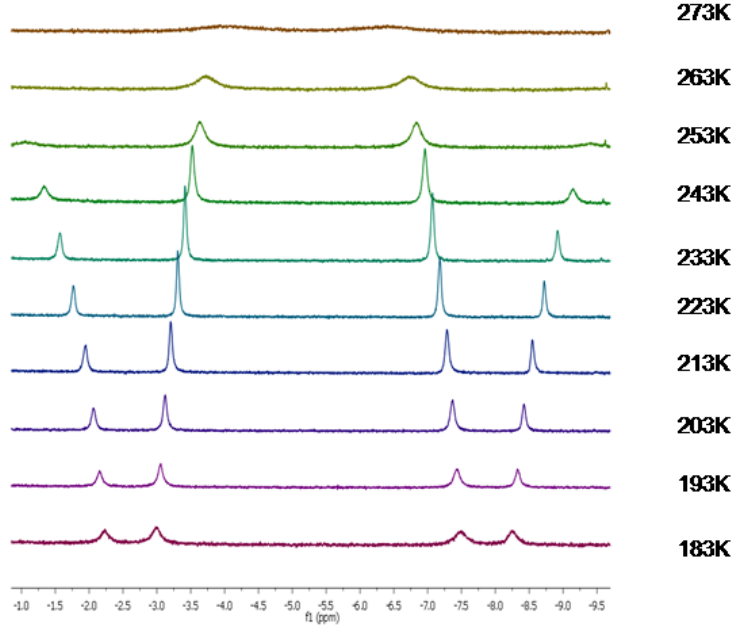

Figure 4. ${ }^{1} \mathrm{H}\left\{{ }^{31} \mathrm{P}\right\}$ NMR spectra of complex 4 in the high-field region as a function of the temperature. 
Table 1. $J_{\mathrm{obs}}(\mathrm{Hz})$ as a function of the temperature for complexes 2-7.

\begin{tabular}{|c|c|c|c|c|c|c|c|c|c|c|c|}
\hline \multirow[t]{2}{*}{ Complex } & \multicolumn{10}{|c|}{ Temperature (K) } & \multirow[t]{2}{*}{$\Delta J_{\text {obs }}$} \\
\hline & 273 & 263 & 253 & 243 & 233 & 223 & 213 & 203 & 193 & 183 & \\
\hline 2 & 35 & 32 & 29 & 27 & 26 & 24 & 23 & 23 & 22 & 21 & 14 \\
\hline 3 & 33 & 29 & 26 & 24 & 23 & 22 & 21 & 18 & 17 & $19^{\mathrm{a}}$ & 14 \\
\hline 4 & $1339^{\mathrm{a}}$ & $1054^{\mathrm{a}}$ & $837^{\mathrm{a}}$ & 657 & 553 & 462 & 377 & 317 & 270 & 224 & 1115 \\
\hline 5 & $3724^{\mathrm{a}}$ & $2691^{\mathrm{a}}$ & $1949^{\mathrm{a}}$ & $1419^{\mathrm{a}}$ & 1030 & 787 & 575 & 422 & 348 & 263 & 3461 \\
\hline 6 & $2409^{a}$ & $1770^{\mathrm{a}}$ & 1233 & 1075 & 698 & 597 & 432 & 311 & 246 & 187 & 2222 \\
\hline 7 & $38314^{\mathrm{b}}$ & $29191^{b}$ & $22300^{\mathrm{b}}$ & $17106^{\mathrm{b}}$ & $13196^{\mathrm{b}}$ & $10256^{\mathrm{b}}$ & $8044^{\mathrm{b}}$ & $6381^{\mathrm{b}}$ & $5130^{\mathrm{b}}$ & $4187^{\mathrm{b}}$ & 34127 \\
\hline
\end{tabular}

${ }^{\mathrm{a}}$ Calculated values using eq $4 .{ }^{\mathrm{b}}$ Estimated values using eq 6 with $a=1.4 \AA, \lambda=1.1 \AA$, and $v=480 \mathrm{~cm}^{-1}$

Table 2. Summary of parameters for complexes 2-7: $T_{1}(\mathrm{~min}), a ; J_{m a g}, \lambda$ and $v$.

\begin{tabular}{|c|c|c|c|c|c|}
\hline Complex & $\begin{array}{c}\mathrm{T}_{1} \min (\mathrm{ms}), \\
300 \mathrm{MHz}\end{array}$ & $a(\AA)$ & $J_{\mathrm{mag}}(\mathrm{Hz})$ & $\lambda(\AA)$ & $v\left(\mathrm{~s}^{-1}\right)$ \\
\hline 2 & 123 & $\begin{array}{c}1.59^{\mathrm{a}} \\
1.67^{\mathrm{b}} \\
1.62(4)^{\mathrm{c}}\end{array}$ & 21 & 1.0 & 575 \\
\hline 3 & 89 & $\begin{array}{l}1.50^{\mathrm{a}} \\
1.68^{\mathrm{b}}\end{array}$ & 18 & 1.0 & 563 \\
\hline 4 & 56 & $\begin{array}{c}1.40^{\mathrm{a}} \\
1.57^{\mathrm{b}} \\
1.47(6)^{\mathrm{c}}\end{array}$ & 27 & 1.0 & 563 \\
\hline 5 & 101 & $\begin{array}{c}1.53^{\mathrm{a}} \\
1.64^{\mathrm{b}} \\
1.48(6)^{\mathrm{c}}\end{array}$ & 25 & 1.1 & 461 \\
\hline 6 & 105 & $\begin{array}{l}1.54^{\mathrm{a}} \\
1.65^{\mathrm{b}}\end{array}$ & 24 & 1.1 & 483 \\
\hline 7 & 46 & $\begin{array}{l}1.34^{\mathrm{a}} \\
1.52^{\mathrm{b}}\end{array}$ & 32 & 1.1 & 480 \\
\hline
\end{tabular}

${ }^{\mathrm{a}}$ from the $T_{1}(\mathrm{~min})$ value. ${ }^{\mathrm{b}}$ DFT calculations. ${ }^{\mathrm{c}} \mathrm{X}$-Ray diffraction analysis.

Eqs 2 and 3 indicate that, for each temperature, the value of $J_{\text {ex }}$ is determined by $a, \lambda$, and $v$, which are characteristic for each compound and considered temperature invariant. Parameter $a$ is the separation between the hydrides, $\lambda$ is the hard sphere radius of the hydrides, and $v$ describes the $\mathrm{H}-\mathrm{M}-\mathrm{H}$ vibrational wag mode which allows movement along the $\mathrm{H}-\mathrm{H}$ vector. Parameters $a, \lambda$, and $v$ have been only determined in a few cases, which include trihydride complexes displaying $\mathrm{A}_{2} \mathrm{~B}$ spin systems. The procedure involves the partial tritiation of the hydride positions, ${ }^{35}$ which quenchs the quantum mechanical exchange coupling. The observed values of $J_{\mathrm{HT}}$ can be then used to ascertain the contribution of $J_{\text {mag }}$ to $J_{\text {obs }}$. Thus, the contribution of $J_{\text {ex }}$ to $J_{\text {obs }}$ can be derived through eq 1 and the corresponding temperature dependency accurately modeled. However, the hydride tritiation is not necessary. ${ }^{36}$ By combining eqs $1-3$, eq 4 is obtained. Now, $J_{\text {obs }}$ is determined by $J_{\text {mag }}$, $\lambda$, and $v$; for a given hydride-hydride separation which can be obtained from $T_{1}$ experiments, neutron and X-ray diffraction analysis, or DFT calculations.

$$
\begin{aligned}
& J_{\text {obs }}=J_{\text {mag }}+2[(2 v \hbar \mathrm{h} / \lambda \mathrm{h} \operatorname{coth}[\mathrm{h} v / 2 \mathrm{hT}]) \\
& \left.\operatorname{Exp}\left\{-2 \pi^{2} \mathrm{~m} v\left(a^{2}+\lambda^{2}\right) / \mathrm{h} \operatorname{coth}[\mathrm{h} v / 2 \mathrm{hT}]\right\}\right]
\end{aligned}
$$

The hydride-hydride separations $(a)$ calculated from the 300 $\mathrm{MHz} T_{1}(\mathrm{~min})$ values of the hydride resonances of $\mathbf{2 - 7 ^ { 3 7 }}$ and those obtained from the optimized structures (B3LYP(LanL2dz,6-31G**)), as well as from the X-ray diffraction analysis of 2, $\mathbf{4}$ and $\mathbf{5}$, are collected in Table 2. The separations obtained from the $T_{1}(\mathrm{~min})$ values agree well with those found by X-ray diffraction analysis whereas are about $0.1 \AA$ shorter than the separations resulting from DFT calculations. Like $\Delta J_{\text {obs, }}$, the $a$ values depend upon the heterocyclic substituent of the starting azetidinone and the charge of the complexes. They decrease in the sequence pyridyl $>$ isoquinolyl $>$ quinolyl and are about $0.1 \AA$ shorter for the salts 
than for the neutral species. Taking $a$ as the separation obtained from $T_{1}(\mathrm{~min})$ values, the $J_{\text {obs }}$ values collected in Table 1 versus the temperature were computed. Figure 5 shows plots of the fits for $\mathbf{5}$ and $\mathbf{6}$, whereas the parameters obtained from the corresponding computer fitting are collected in Table 2. $J_{\text {mag }}$ vary from 18 to $27 \mathrm{~Hz}$, being between 4 and $6 \mathrm{~Hz}$ higher for the salts $\mathbf{5}$ and $\mathbf{6}$ than for the respective neutral species $\mathbf{2}$ and 4. Parameter $\lambda$ increases about $10 \%$ in the salts with regard to the neutral complexes, whereas the $v$ values decrease about $20 \%$ in the same vein. In contrast to the charge, the substituent of the azetidinone has not any significant influence on both parameters.

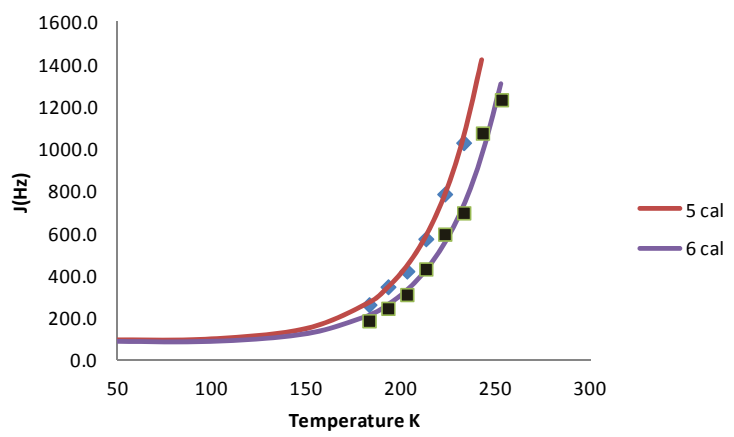

Figure 5. Plots of $J_{\text {obs }}$ versus temperature for complexes $\mathbf{5}$ and 6.

The quantification method described by eq 4. has some predictive character when families of related compounds are compared. The quantum mechanical exchange coupling is mainly intensive for 7 . Thus, $J_{\text {obs }}$ values could not be directly obtained from the respective ${ }^{1} \mathrm{H}$ NMR spectra. However, the $J_{\mathrm{mag}}, \lambda$, and $v$ parameters can be estimated on the basis of the previously mentioned tendencies, starting from those computed for its neutral counterpart $\mathbf{4}$, and refined according to eq 4 to afford the $J_{\text {obs }}$ values shown in Table 1 .

\section{CONCLUDING REMARKS}

This study reveals that 2-azetidinones substituted at 4-position with an N-heterocycle and at 3-position with a phenoxy group generate $\mathrm{CC}^{\prime} \mathrm{N}$-pincer ligands through a metal-mediated degradation involving two $\mathrm{C}-\mathrm{H}$ bond activations and the breakage of parallel C-N and C-C bonds in a type B-rupture of the fourmembered ring. As a proof of concept, novel neutral and cationic dihydride-osmium(IV) complexes have been prepared from the reactions of the hexahydride complex $\mathrm{OsH}_{6}\left(\mathrm{P}^{\mathrm{i}} \mathrm{Pr}_{3}\right)_{2}$ with the corresponding 2-azetidinones and characterized by $\mathrm{X}$ ray diffraction analysis and spectroscopically.

The hydride ligands of the new compounds undergo quantum mechanical exchange coupling, which is particularly intense for the salts. The phenomenon has been experimentally quantifed according to a two dimensional harmonic oscillator model, where the term $J_{\text {ex }}$ is determined by the separation between the hydrides, their hard sphere radius, and the parameter $v$ describing the H-M-H vibrational wag mode allowing movement along the $\mathrm{H}-\mathrm{H}$ vector. The analysis and comparison of the obtained data show that there are significant differences between the salts and the respective neutral species. Thus, it is observed that in the cationic compounds the separation between the hydrides ligands is about $0.1 \AA$ shorter, the hydride hard sphere radius increases about $10 \%$, and the $v$ value de- creases about $20 \%$.

In conclusion, $\beta$-lactams, with important applications in organic synthesis, ${ }^{38}$ should be also taken into account in coordination chemistry because their metal-mediated productive degradation leads to novel pincer ligands, which allow to stabilize transition metal complexes with interesting spectroscopic properties.

\section{EXPERIMENTAL SECTION}

General Information. All reactions were carried out with rigorous exclusion of air using Schlenk-tube techniques. Solvents were obtained oxygen- and water-free from an MBraun or PS-MD-5 solvent purification apparatus. ${ }^{1} \mathrm{H},{ }^{13} \mathrm{C}\left\{{ }^{1} \mathrm{H}\right\}$ and ${ }^{31} \mathrm{P}\left\{{ }^{1} \mathrm{H}\right\}$ NMR spectra were recorded on Bruker $300 \mathrm{ARX}$, Bruker Avance $300 \mathrm{MHz}$, Bruker Avance $400 \mathrm{MHz}$ or Bruker Avance $500 \mathrm{MHz}$ instruments. Chemical shifts (expressed in parts per million) are referenced to residual solvent peaks $\left({ }^{1} \mathrm{H}\right.$, $\left.{ }^{13} \mathrm{C}\left\{{ }^{1} \mathrm{H}\right\}\right)$, or external $85 \% \mathrm{H}_{3} \mathrm{PO}_{4}\left({ }^{31} \mathrm{P}\left\{{ }^{1} \mathrm{H}\right\}\right)$. Coupling constants $J$ and $N$ are given in hertz. Attenuated total reflection infrared spectra (ATR-IR) of solid samples were run on a Perkin-Elmer Spectrum 100 FT-IR spectrometer. C, H, and N analyses were carried out in a Perkin-Elmer $2400 \mathrm{CHNS} / \mathrm{O}$ analyzer. High-resolution electrospray mass spectra were acquired using a MicroTOF-Q hybrid quadrupole time-offlight spectrometer (Bruker Daltonics, Bremen, Germany). $\mathrm{OsH}_{6}\left(\mathrm{P}^{\mathrm{i}} \mathrm{Pr}_{3}\right)_{2}{ }^{39}$ and $\mathbf{I}$, II, and III were prepared by published methods. ${ }^{14}$

Preparation of 2. A colorless solution of $\mathrm{OsH}_{6}\left(\mathrm{P}^{i} \mathrm{Pr}_{3}\right)_{2}(100$ $\mathrm{mg}, 0,193 \mathrm{mmol})$ in toluene $(10 \mathrm{~mL})$ was treated with $\mathbf{I}(49$ $\mathrm{mg}, 0.193 \mathrm{mmol}$ ) and heated under reflux during $6 \mathrm{~h}$. After this time, the resulting solution was evaporated to dryness. The residue was dissolved in pentane and filtered through Celite and the solvent was removed in vacuo. The subsequent addition of methanol to the residue afforded a yellow solid that was washed with methanol $(3 \times 2 \mathrm{~mL})$ in a ${ }^{i} \mathrm{PrOH} /$ dry ice bath and dried in vacuo. Yield: $98 \mathrm{mg}$ (71\%). Anal. Calcd for $\mathrm{C}_{31} \mathrm{H}_{53} \mathrm{NOOsP}_{2}$ : C, 52.10; H, 8.03; N, 1.91. Found: C, 52.49; $\mathrm{H}, 7.64 ; \mathrm{N}, 1.97$. HRMS (electrospray, $\mathrm{m} / \mathrm{z}$ ): calcd. for $\mathrm{C}_{31} \mathrm{H}_{52} \mathrm{NOOsP}_{2}[\mathrm{M}-\mathrm{H}]^{+}$: 708.3135, found: 708.3270. IR $\left(\mathrm{cm}^{-1}\right)$ : $v(\mathrm{OsH}) 2185$ (w), 2068 (w). ${ }^{1} \mathrm{H}$ NMR (300 MHz, C $6 \mathrm{D}_{6}, 298$ $\mathrm{K}): \delta 8.43\left(\mathrm{~d}, J_{\mathrm{H}-\mathrm{H}}=5.9,1 \mathrm{H}, \mathrm{CH}\right.$ py), $7.58\left(\mathrm{~d}, J_{\mathrm{H}-\mathrm{H}}=7.2,1 \mathrm{H}\right.$, $\mathrm{CH} \mathrm{Ph}), 7.16(\mathrm{br}, 1 \mathrm{H}, \mathrm{CH} \mathrm{Ph}), 6.94\left(\mathrm{t}, J_{\mathrm{H}-\mathrm{H}}=7.2,1 \mathrm{H}, \mathrm{CH} \mathrm{Ph}\right)$, $6.71(\mathrm{~m}, 2 \mathrm{H}, \mathrm{CH} \mathrm{Ph}$ and $\mathrm{Os}-\mathrm{C}=\mathrm{CH}), 6.62(\mathrm{br}, 1 \mathrm{H}, \mathrm{CH}$ py), 6.61 (br, 1H, CH py), 5.77 (m, 1H, CH py), $1.93(\mathrm{~m}, 6 \mathrm{H}$, $\left.\mathrm{PCH}\left(\mathrm{CH}_{3}\right)_{2}\right), 1.06\left(\mathrm{dvt}, J_{\mathrm{H}-\mathrm{H}}=6.9, N=12.6,18 \mathrm{H}\right.$, $\left.\mathrm{PCH}\left(\mathrm{CH}_{3}\right)_{2}\right), 0.98$ (dvt, $J_{\mathrm{H}-\mathrm{H}}=7.2, N=12.6,18 \mathrm{H}$, $\left.\mathrm{PCH}\left(\mathrm{CH}_{3}\right)_{2}\right),-4.25$ (br, $\left.1 \mathrm{H}, \mathrm{OsH}\right),-7.80$ (br, $\left.1 \mathrm{H}, \mathrm{OsH}\right)$. ${ }^{1} \mathrm{H}\left\{{ }^{31} \mathrm{P}\right\}$ NMR (400 MHz, $\mathrm{C}_{7} \mathrm{D}_{8}, 273 \mathrm{~K}$, high field region): $\delta$ $4.24\left(\mathrm{~d}, J_{\mathrm{H}-\mathrm{H}}=34.5, \mathrm{OsH}\right),-7.89\left(\mathrm{~d}, J_{\mathrm{H}-\mathrm{H}}=34.5, \mathrm{OsH}\right) . T_{1}$ (min) (ms, OsH, 300MHz, $\left.\mathrm{C}_{7} \mathrm{D}_{8}, 223 \mathrm{~K}\right): 123 \pm 4 .{ }^{31} \mathrm{P}\left\{{ }^{1} \mathrm{H}\right\}$ NMR (121.4 MHz, $\left.\mathrm{C}_{6} \mathrm{D}_{6}, 298 \mathrm{~K}\right): \delta 4.2$ (s). ${ }^{13} \mathrm{C}\left\{{ }^{1} \mathrm{H}\right\}$-APT NMR, HMBC and HSQC (75.5 MHz, $\left.\mathrm{C}_{6} \mathrm{D}_{6}, 298 \mathrm{~K}\right): \delta 248.3$ $\left(\mathrm{t}, J_{\mathrm{C}-\mathrm{P}}=4.9, \mathrm{OsCO}\right), 174.8\left(\mathrm{~s}, \mathrm{C}\right.$ py), $170.8\left(\mathrm{t}, J_{\mathrm{C}-\mathrm{P}}=1.3, \mathrm{C}\right.$ $\mathrm{PhO}), 157.7$ (s, CH py), 145.1 (t, $\left.J_{\mathrm{C}-\mathrm{P}}=1.0, \mathrm{CH} \mathrm{Ph}\right), 136.6(\mathrm{t}$, $J_{\text {C-P }}=6.9$, OsC Ph), $134.3\left(\mathrm{~s}, \mathrm{CH}\right.$ py), $122.6\left(\mathrm{t}, J_{\mathrm{C}-\mathrm{P}}=1.1, \mathrm{CH}\right.$ $\mathrm{Ph}), 122.5\left(\mathrm{t}, J_{\mathrm{C}-\mathrm{P}}=1.1, \mathrm{CH} \mathrm{Ph}\right), 117.9(\mathrm{~s}, \mathrm{CH}$ py), $113.2(\mathrm{~s}$, $\mathrm{CH}$ py), 109.7 (s, CH Ph), $106.7(\mathrm{~s}, \mathrm{Os}-\mathrm{C}=\mathrm{CH}), 26.5$ (vt, $N=$ 12.4, $\left.\mathrm{PCH}\left(\mathrm{CH}_{3}\right)_{2}\right), 19.7\left(\mathrm{~s}, \mathrm{PCH}\left(\mathrm{CH}_{3}\right)_{2}\right), 19.2\left(\mathrm{~s}, \mathrm{PCH}\left(\mathrm{CH}_{3}\right)_{2}\right)$.

Preparation of 3 A colorless solution of $\mathrm{OsH}_{6}\left(\mathrm{P}^{i} \mathrm{Pr}_{3}\right)_{2}(100$ $\mathrm{mg}, 0,193 \mathrm{mmol})$ in toluene $(10 \mathrm{~mL})$ was treated with II (58 $\mathrm{mg}, 0.193 \mathrm{mmol}$ ) and heated under reflux during $12 \mathrm{~h}$. After this time, the resulting solution was evaporated to dryness. 
The residue was solved in pentane and filtered through Celite and the solvent was removed in vacuo. The subsequent addition of methanol to the residue afforded a red solid that was washed with methanol $(3 \times 2 \mathrm{~mL})$ in a ${ }^{i} \mathrm{PrOH} /$ dry ice bath and dried in vacuo. Yield $87 \mathrm{mg}(60 \%)$. Anal. Calcd for $\mathrm{C}_{35} \mathrm{H}_{55} \mathrm{NOOsP}_{2}$ : C, 55.44; H, 7.31; N, 1.84. Found: C, 55.13; $\mathrm{H}, 7.37 ; \mathrm{N}, 2.03$. HRMS (electrospray, $m / z$ ): calcd. for $\mathrm{C}_{35} \mathrm{H}_{54} \mathrm{NOOSP}_{2}[\mathrm{M}-\mathrm{H}]^{+}:$758.3287, found: 758.3292. IR $\left(\mathrm{cm}^{-1}\right)$ : $v(\mathrm{OsH}) 2110(\mathrm{w}), 2100(\mathrm{w}) .{ }^{1} \mathrm{H}$ NMR $\left(400 \mathrm{MHz}, \mathrm{C}_{6} \mathrm{D}_{6}, 298\right.$ $\mathrm{K}): \delta 8.33\left(\mathrm{~d}, J_{\mathrm{H}-\mathrm{H}}=6.6,1 \mathrm{H}, \mathrm{CH}\right.$ isqn), $7.89\left(\mathrm{~d}, J_{\mathrm{H}-\mathrm{H}}=7.3,1 \mathrm{H}\right.$, $\mathrm{CH} \mathrm{Ph}), 7.60\left(\mathrm{~d}, J_{\mathrm{H}-\mathrm{H}}=7.2,1 \mathrm{H}, \mathrm{CH}\right.$ isqn), 7.54 (s, $1 \mathrm{H}$, Os$\mathrm{C}=\mathrm{CH}), 7.25\left(\mathrm{~d}, J_{\mathrm{H}-\mathrm{H}}=8.7,1 \mathrm{H}, \mathrm{CH} \mathrm{Ph}\right), 7.21\left(\mathrm{~d}, J_{\mathrm{H}-\mathrm{H}}=7.7\right.$, $1 \mathrm{H}, \mathrm{CH} \mathrm{Ph}), 7.06\left(\mathrm{~m}, 2 \mathrm{H}, \mathrm{CH}\right.$ isqn), $6.95\left(\mathrm{t}, J_{\mathrm{H}-\mathrm{H}}=7.4,1 \mathrm{H}, \mathrm{CH}\right.$ isqn), $6.72\left(\mathrm{t}, 1 \mathrm{H}, J_{\mathrm{H}-\mathrm{H}}=7.2, \mathrm{CH} \mathrm{Ph}\right), 6.30\left(\mathrm{~d}, 1 \mathrm{H}, J_{\mathrm{H}-\mathrm{H}}=6.6\right.$, $\mathrm{CH}$ isqn), $1.96\left(\mathrm{~m}, 6 \mathrm{H}, \mathrm{PCH}\left(\mathrm{CH}_{3}\right)_{2}\right), 1.04\left(\mathrm{dvt}, J_{\mathrm{H}-\mathrm{H}}=6.8, N=\right.$ $\left.12.8,18 \mathrm{H}, \mathrm{PCH}\left(\mathrm{CH}_{3}\right)_{2}\right), 0.92\left(\mathrm{dvt}, J_{\mathrm{H}-\mathrm{H}}=6.8, N=12.6,18 \mathrm{H}\right.$, $\left.\mathrm{PCH}\left(\mathrm{CH}_{3}\right)_{2}\right),-3.92$ (br, 1H, OsH), -7.61 (br, 1H, OsH) -3.82 $\left(\mathrm{d}, J_{\mathrm{H}-\mathrm{H}}=21.7, \mathrm{OsH}\right),-7.51\left(\mathrm{~d}, J_{\mathrm{H}-\mathrm{H}}=21.5, \mathrm{OsH}\right) T_{1}(\mathrm{~min})(\mathrm{ms}$, OsH, 300MHz, $\left.\mathrm{C}_{7} \mathrm{D}_{8}, 233 \mathrm{~K}\right): 89 \pm 4 .{ }^{31} \mathrm{P}\left\{{ }^{1} \mathrm{H}\right\} \mathrm{NMR}(161.8$ $\left.\mathrm{MHz}, \mathrm{C}_{6} \mathrm{D}_{6}, 298 \mathrm{~K}\right): \delta 7.1(\mathrm{~s}) .{ }^{13} \mathrm{C}\left\{{ }^{1} \mathrm{H}\right\}$-APT NMR, HMBC and HSQC $\left(100.5 \mathrm{MHz}, \mathrm{C}_{6} \mathrm{D}_{6}, 298 \mathrm{~K}\right): \delta 256.1\left(\mathrm{t}, J_{\mathrm{C}-\mathrm{P}}=4.0\right.$, OsCO), 173.8 (s, C isqn), 170.7 (s, C PhO), 152.5 (s, CH isqn), 145.0 ( $\mathrm{s}, \mathrm{CH}$ isqn), $137.0\left(\mathrm{t}, J_{\mathrm{C}-\mathrm{P}}=6.7, \mathrm{OsC} \mathrm{Ph}\right), 135.1$ (s, C isqn), 129.8 (s, CH isqn), 127.4 (s, CH Ph), 126.0 (s, CH $\mathrm{Ph}), 125.8$ (s, CH Ph), 125.5 (s, C isqn), 123.0 (s, $\mathrm{CH}$ isqn), 122.6 (s, CH isqn), 111.7 (s, $\mathrm{CH}$ isqn), $110.0(\mathrm{~s}, \mathrm{CH} \mathrm{Ph}, 105.5$ (s, Os-C=CH), 26.9 (vt, $\left.N=25.0, \mathrm{PCH}\left(\mathrm{CH}_{3}\right)_{2}\right), 19.7$ (s, $\left.\operatorname{PCH}\left(\mathrm{CH}_{3}\right)_{2}\right), 19.1\left(\mathrm{~s}, \mathrm{PCH}\left(\mathrm{CH}_{3}\right)_{2}\right)$.

Preparation of 4. A colorless solution of $\mathrm{OsH}_{6}\left(\mathrm{P}^{i} \mathrm{Pr}_{3}\right)_{2}(100$ $\mathrm{mg}, 0,193 \mathrm{mmol})$ in toluene $(10 \mathrm{~mL})$ was treated with III $(58$ $\mathrm{mg}, 0.193 \mathrm{mmol}$ ) and heated under reflux during $12 \mathrm{~h}$. After this time, the resulting solution was evaporated to dryness. The residue was solved in pentane and filtered through Celite and the solvent was removed in vacuo. The subsequent addition of methanol to the residue afforded a red solid that was washed with methanol $(3 \times 2 \mathrm{~mL})$ in a ${ }^{i} \mathrm{PrOH} /$ dry ice bath and dried in vacuo. Yield $93 \mathrm{mg}(63 \%)$. Anal. Calcd for $\mathrm{C}_{35} \mathrm{H}_{55} \mathrm{NOOsP}_{2}$ : C, 55.44; H, 7.31; N, 1.84. Found: C, 55.59; $\mathrm{H}, 7.24 ; \mathrm{N}, 2.01$. HRMS (electrospray, $\mathrm{m} / \mathrm{z}$ ): calcd. for $\mathrm{C}_{35} \mathrm{H}_{54} \mathrm{NOOsP}_{2}[\mathrm{M}-\mathrm{H}]^{+}:$758.3292, found: $758.3268 \mathrm{IR}\left(\mathrm{cm}^{-1}\right)$ : $v(\mathrm{OsH}) 2161(\mathrm{w}), 2150$ (w). ${ }^{1} \mathrm{H}$ NMR $\left(400 \mathrm{MHz}, \mathrm{C}_{6} \mathrm{D}_{6}, 298\right.$ $\mathrm{K}): \delta 9.08\left(\mathrm{~d}, J_{\mathrm{H}-\mathrm{H}}=8.7,1 \mathrm{H}, \mathrm{CH}\right.$ qn $), 7.72\left(\mathrm{~d}, J_{\mathrm{H}-\mathrm{H}}=6.5,1 \mathrm{H}\right.$, $\mathrm{CH} \mathrm{Ph}), 7.37$ (m, 1H, CH qn), 7.22 (m, 2H, CH qn), 6.97 (m, $4 \mathrm{H}, \mathrm{CH} \mathrm{Ph}, \mathrm{CH}$ qn, Os-C $=\mathrm{CH}), 6.85\left(\mathrm{~d}, J_{\mathrm{H}-\mathrm{H}}=8.8,1 \mathrm{H}, \mathrm{CH}\right.$ qn), $6.73\left(\mathrm{td}, J_{\mathrm{H}-\mathrm{H}}=7.3, J_{\mathrm{H}-\mathrm{P}}=1.3,1 \mathrm{H}, \mathrm{CH} \mathrm{Ph}\right), 1,70(\mathrm{~m}, 6 \mathrm{H}$, $\left.\mathrm{PCH}\left(\mathrm{CH}_{3}\right)_{2}\right), 1.02\left(\mathrm{dvt}, J_{\mathrm{H}-\mathrm{H}}=6.8, N=12,8,18 \mathrm{H}\right.$, $\left.\mathrm{PCH}\left(\mathrm{CH}_{3}\right)_{2}\right), 0.87\left(\mathrm{dvt}, J_{\mathrm{H}-\mathrm{H}}=6.8, N=12,6,18 \mathrm{H}\right.$, $\left.\mathrm{PCH}\left(\mathrm{CH}_{3}\right)_{2}\right),-5.18$ (br, $\left.2 \mathrm{H}, \mathrm{OsH}\right) .{ }^{1} \mathrm{H}\left\{{ }^{31} \mathrm{P}\right\}$ NMR (300 MHz, $\mathrm{C}_{7} \mathrm{D}_{8}, 243 \mathrm{~K}$, high field region): $\delta-5.24$ (AB spin system, $\Delta v=$ $\left.1547, J_{\mathrm{A}-\mathrm{B}}=657,2 \mathrm{H}, \mathrm{OsH}\right) . T_{1}(\mathrm{~min})(\mathrm{ms}, \mathrm{OsH}, 300 \mathrm{MHz}$, $\left.\mathrm{C}_{7} \mathrm{D}_{8}, 223 \mathrm{~K}\right): 56 \pm 4 .{ }^{31} \mathrm{P}\left\{{ }^{1} \mathrm{H}\right\} \mathrm{NMR}\left(121.5 \mathrm{MHz}, \mathrm{C}_{6} \mathrm{D}_{6}, 298\right.$ $\mathrm{K}): \delta 4.0(\mathrm{~s}) .{ }^{13} \mathrm{C}\left\{{ }^{1} \mathrm{H}\right\}$-APT NMR, HMBC and HSQC $(75.5$ $\mathrm{MHz}, \mathrm{C}_{6} \mathrm{D}_{6}, 298 \mathrm{~K}$ ): $\delta 256.3$ (t, $J_{\mathrm{C}-\mathrm{P}}=4.5$, OsCO), $176.2(\mathrm{~s}, \mathrm{C}$ qn), 170.1 (s, C PhO), 149.0 (s, C qn), 145.3 (s, CH Ph), 135.8 $\left(\mathrm{t}, J_{\mathrm{C}-\mathrm{P}}=6.8, \mathrm{OsC} \mathrm{Ph}\right), 134.4(\mathrm{~s}, \mathrm{CH} \mathrm{Ph}), 129.8(\mathrm{~s}, \mathrm{CH} \mathrm{qn})$, 128.8-128.7 (s, CH qn, CH Ph), 123.8 (s, C qn), 122.3-122.2 (s, CH Ph, CH qn), 121.8 (s, CH qn), 120.3 (s, CH qn), 111.2 (s, Os-C=CH), 110.3 (s, $\mathrm{CH}$ qn), 27.4 (vt, $N=25.0$, $\left.\mathrm{PCH}\left(\mathrm{CH}_{3}\right)_{2}\right), 20.2\left(\mathrm{~s}, \mathrm{PCH}\left(\mathrm{CH}_{3}\right)_{2}\right), 19.2\left(\mathrm{~s}, \mathrm{PCH}\left(\mathrm{CH}_{3}\right)_{2}\right)$.

Preparation of 5. A yellow solution of $2(100 \mathrm{mg}, 0.141$ mmol) in $5 \mathrm{~mL}$ of diethyl ether was treated with 1 equiv of $\mathrm{HBF}_{4} \cdot \mathrm{OEt}_{2}(19.4 \mu \mathrm{L}, 0.141 \mathrm{mmol})$ and stirred for $15 \mathrm{~min}$ at room temperature. During the course of the reaction a white solid was formed. The solvent was removed, and the solid was washed with further portions of diethyl ether and dried in vacuo. Yield: $107.1 \mathrm{mg}(96 \%)$. Anal. Calcd for $\mathrm{C}_{31} \mathrm{H}_{54} \mathrm{NOOSP}_{2} \mathrm{BF}_{4}$ : C, 46.79; H, 6.83; N, 1.76. Found: C, 46.56; H, 6.44; N, 1.60. HRMS (electrospray, $\mathrm{m} / \mathrm{z}$ ): calcd. for $\mathrm{C}_{31} \mathrm{H}_{52} \mathrm{NOOsP}_{2}[\mathrm{M}-2 \mathrm{H}]^{+}:$708.3148, found: 708.3135. IR ( $\mathrm{cm}^{-}$ $\left.{ }^{1}\right): v(\mathrm{OsH}) 2049(\mathrm{w}), 1927(\mathrm{w}), \mathrm{v}\left(\mathrm{BF}_{4}\right) 1050$ (br). ${ }^{1} \mathrm{H}$ NMR $\left(300 \mathrm{MHz}, \mathrm{CD}_{2} \mathrm{Cl}_{2}, 298 \mathrm{~K}\right): \delta 8.92\left(\mathrm{~d}, J_{\mathrm{H}-\mathrm{H}}=6.9,1 \mathrm{H}, \mathrm{CH}\right.$ py), $7.96\left(\mathrm{t}, J_{\mathrm{H}-\mathrm{H}}=6.9,1 \mathrm{H}, \mathrm{CH}\right.$ py $), 7.76\left(\mathrm{~d}, J_{\mathrm{H}-\mathrm{H}}=6.9,1 \mathrm{H}, \mathrm{CH}\right.$ py), $7.43\left(\mathrm{~d}, J_{\mathrm{H}-\mathrm{H}}=7.5,1 \mathrm{H}, \mathrm{CH} \mathrm{Ph}\right), 7.34(\mathrm{~m}, 2 \mathrm{H}, \mathrm{CH}$ py, CH $\mathrm{Ph}), 7.05\left(\mathrm{t}, J_{\mathrm{H}-\mathrm{H}}=7.5,1 \mathrm{H}, \mathrm{CH} \mathrm{Ph}\right), 6.83\left(\mathrm{t}, J_{\mathrm{H}-\mathrm{H}}=7.4,1 \mathrm{H}, \mathrm{CH}\right.$ $\mathrm{Ph}), 4.11\left(\mathrm{~s}, 2 \mathrm{H}, \mathrm{CH}_{2}\right), 1.84\left(\mathrm{~m}, 6 \mathrm{H}, \mathrm{PCH}\left(\mathrm{CH}_{3}\right)_{2}\right), 0.94$ (2 dvt, overlapped, $\left.J_{\mathrm{H}-\mathrm{H}}=6.9, N=12.3,36 \mathrm{H}, \mathrm{PCH}\left(\mathrm{CH}_{3}\right)_{2}\right),-4.10$ (br, $1 \mathrm{H}, \mathrm{OsH}),-4.72$ (br, $1 \mathrm{H}, \mathrm{OsH}) .{ }^{1} \mathrm{H}\left\{{ }^{31} \mathrm{P}\right\}$ NMR $(300 \mathrm{MHz}$, $\mathrm{CD}_{2} \mathrm{Cl}_{2}, 223 \mathrm{~K}$, high field region): $\delta-5.24$ (AB spin system, $\left.\Delta v=2799, J_{\mathrm{A}-\mathrm{B}}=787,2 \mathrm{H}, \mathrm{OsH}\right) . T_{1}(\mathrm{~min})(\mathrm{ms}, \mathrm{OsH}, 300$ $\left.\mathrm{MHz}, \mathrm{CD}_{2} \mathrm{Cl}_{2}, 193 \mathrm{~K}\right): 101 \pm 4 .{ }^{31} \mathrm{P}\left\{{ }^{1} \mathrm{H}\right\}$ NMR $(121.5 \mathrm{MHz}$, $\left.\mathrm{CD}_{2} \mathrm{Cl}_{2}, 298 \mathrm{~K}\right): \delta 18.8$ (s). ${ }^{13} \mathrm{C}\left\{{ }^{1} \mathrm{H}\right\}$-APT NMR, HMBC and HSQC (75.5 MHz, $\mathrm{CD}_{2} \mathrm{Cl}_{2}, 298 \mathrm{~K}$ ): $\delta 298.1$ (s, OsCO), 168.7 (s, C PhO), 164.6 (s, C py), 158.6 (s, CH py), 145.2 (s, CH $\mathrm{Ph}), 139.9$ (s, CH py), 132.8 (t, $J_{\mathrm{C}-\mathrm{P}}=5.3$, OsC Ph), 126.7 (s, $\mathrm{CH}$ py), 126.1 (s, CH Ph), 124.3 (s, CH py), 124.2 (s, CH Ph), $113.8(\mathrm{~s}, \mathrm{CH} \mathrm{Ph}), 62.7\left(\mathrm{~s}, \mathrm{CH}_{2}\right), 26.8$ (vt, $N=27.5$, $\left.\mathrm{PCH}\left(\mathrm{CH}_{3}\right)_{2}\right), 19.1\left(\mathrm{~s}, \mathrm{PCH}\left(\mathrm{CH}_{3}\right)_{2}\right), 19.0\left(\mathrm{~s}, \mathrm{PCH}\left(\mathrm{CH}_{3}\right)_{2}\right)$.

Preparation of 6. A red solution of $3(50 \mathrm{mg}, 0.066 \mathrm{mmol})$ in $5 \mathrm{~mL}$ of diethyl ether was treated with 1 equiv of $\mathrm{HBF}_{4} \cdot \mathrm{OEt}_{2}$ $(9.00 \mu \mathrm{L}, 0.066 \mathrm{mmol})$ and stirred for $15 \mathrm{~min}$ at room temperature. During the course of the reaction a white solid was formed. The solvent was removed, and the solid was washed with further portions of diethyl ether and dried in vacuo. Yield: $103.1 \mathrm{mg}(92 \%)$. Anal. Calcd for $\mathrm{C}_{35} \mathrm{H}_{56} \mathrm{NOOsP}_{2} \mathrm{BF}_{4}$ : C, 49.70; H, 6.67; N, 1.65. Found: C, 49.54; H, 6.83; N, 1.74 . IR $\left(\mathrm{cm}^{-1}\right): v(\mathrm{OsH}) 2165(\mathrm{w}), 2048(\mathrm{w}), \mathrm{v}\left(\mathrm{BF}_{4}\right) 1053(\mathrm{br}) .{ }^{1} \mathrm{H}$ NMR (400 MHz, $\left.\mathrm{CD}_{2} \mathrm{Cl}_{2}, 298 \mathrm{~K}\right): \delta 8.73\left(\mathrm{~d}, J_{\mathrm{H}-\mathrm{H}}=6.5,1 \mathrm{H}\right.$, $\mathrm{CH}$ isqn), $8.18\left(\mathrm{~d}, J_{\mathrm{H}-\mathrm{H}}=8.0,1 \mathrm{H}, \mathrm{CH} \mathrm{Ph}\right), 8.05\left(\mathrm{~d}, J_{\mathrm{H}-\mathrm{H}}=7.5\right.$, $1 \mathrm{H}, \mathrm{CH}$ isqn), $7.90\left(\mathrm{~m}, 2 \mathrm{H}, \mathrm{CH}\right.$ isqn), $7.74\left(\mathrm{~d}, 1 \mathrm{H}, J_{\mathrm{H}-\mathrm{H}}=6.4\right.$, $\mathrm{CH}$ isqn), $7.45\left(\mathrm{~d}, J_{\mathrm{H}-\mathrm{H}}=7.2,1 \mathrm{H}, \mathrm{CH} \mathrm{Ph}\right), 7.42\left(\mathrm{~d}, J_{\mathrm{H}-\mathrm{H}}=8.0\right.$, $1 \mathrm{H}, \mathrm{CH} \mathrm{Ph}), 7.07\left(\mathrm{t}, J_{\mathrm{H}-\mathrm{H}}=7.3,1 \mathrm{H}, \mathrm{CH}\right.$ isqn), $6.85\left(\mathrm{t}, 1 \mathrm{H}, J_{\mathrm{H}-\mathrm{H}}\right.$ $=7.2, \mathrm{CH} \mathrm{Ph}), 4.43\left(\mathrm{~s}, 2 \mathrm{H}, \mathrm{CH}_{2}\right), 1.88\left(\mathrm{~m}, 6 \mathrm{H}, \mathrm{PCH}\left(\mathrm{CH}_{3}\right)_{2}\right)$, $0.97\left(\mathrm{dvt}, J_{\mathrm{H}-\mathrm{H}}=7.2, N=13.6,18 \mathrm{H}, \mathrm{PCH}\left(\mathrm{CH}_{3}\right)_{2}\right), 0.89(\mathrm{dvt}$, $\left.J_{\mathrm{H}-\mathrm{H}}=6.8, N=13.6,18 \mathrm{H}, \mathrm{PCH}\left(\mathrm{CH}_{3}\right)_{2}\right),-4.16(\mathrm{br}, 2 \mathrm{H}, \mathrm{OsH})$. ${ }^{1} \mathrm{H}\left\{{ }^{31} \mathrm{P}\right\}$ NMR (300 MHz, $\mathrm{CD}_{2} \mathrm{Cl}_{2}, 223 \mathrm{~K}$, high field region): $\delta$ -4.53 (AB spin system, $\Delta v=1533 J_{\mathrm{A}-\mathrm{B}}=698,2 \mathrm{H}, \mathrm{OsH}$ ). $T_{1}$ (min) (ms, OsH, 300MHz, $\left.\mathrm{CD}_{2} \mathrm{Cl}_{2}, 193 \mathrm{~K}\right): 105 \pm 4 .{ }^{31} \mathrm{P}\left\{{ }^{1} \mathrm{H}\right\}$ NMR (121.5 MHz, $\left.\mathrm{CD}_{2} \mathrm{Cl}_{2}, 298 \mathrm{~K}\right): \delta 19.8(\mathrm{~s}) .{ }^{13} \mathrm{C}\left\{{ }^{1} \mathrm{H}\right\}$-APT NMR, HMBC and HSQC (75.5 MHz, $\left.\mathrm{CD}_{2} \mathrm{Cl}_{2}, 298 \mathrm{~K}\right): \delta$ 296.1 (s, OsCO), 169.0 (s, C isqn), 165.4 (s, C PhO), 150.6 (s, $\mathrm{CH}$ isqn), 145.5 (s, CH Ph), 135.7 (s, OsC Ph), 133.7 (s, CH isqn), 133.0 ( $\mathrm{s}, \mathrm{C}$ isqn), 131.1 ( $\mathrm{s}, \mathrm{CH}$ isqn), 128.3 ( $\mathrm{s}, \mathrm{CH}$ isqn), 127.1 (s, C isqn), 126.9 (s, CH Ph), 126.4 (s, CH Ph), 125.5 (s, $\mathrm{CH}$ isqn), 124.6 (s, $\mathrm{CH}$ isqn), 114.1 (s, $\mathrm{CH} \mathrm{Ph}), 62.4\left(\mathrm{~s}, \mathrm{CH}_{2}\right)$, 27.3 (vt, $\left.N=27.6, \mathrm{PCH}\left(\mathrm{CH}_{3}\right)_{2}\right), 19.2\left(\mathrm{~s}, \mathrm{PCH}\left(\mathrm{CH}_{3}\right)_{2}\right)$.

Preparation of 7. A red solution of $4(50 \mathrm{mg}, 0.066 \mathrm{mmol})$ in $5 \mathrm{~mL}$ of diethyl ether was treated with 1 equiv of $\mathrm{HBF}_{4} \cdot \mathrm{OEt}_{2}$ $(9.00 \mu \mathrm{L}, 0.066 \mathrm{mmol})$ and stirred for $15 \mathrm{~min}$ at room temperature. During the course of the reaction a white solid was formed. The solvent was removed, and the solid was washed with further portions of diethyl ether and dried in vacuo. Yield: $98.3 \mathrm{mg}(89 \%)$. Anal. Calcd for $\mathrm{C}_{35} \mathrm{H}_{56} \mathrm{NOOSP}_{2} \mathrm{BF}_{4}$ : C, 49.70; H, 6.67; N, 1.65. Found: C, 49.85; H, 6.54; N, 1.34. IR $\left(\mathrm{cm}^{-1}\right): \mathrm{v}(\mathrm{OsH}) 1971(\mathrm{w}), 1914(\mathrm{w}), \mathrm{v}\left(\mathrm{BF}_{4}\right) 1056(\mathrm{br}) .{ }^{1} \mathrm{H}$ 
NMR $\left(300 \mathrm{MHz}, \mathrm{CD}_{2} \mathrm{Cl}_{2}, 298 \mathrm{~K}\right): \delta 8.83\left(\mathrm{~d}, J_{\mathrm{H}-\mathrm{H}}=8.9,1 \mathrm{H}\right.$, $\mathrm{CH}$ qn), $8.42\left(\mathrm{~d}, J_{\mathrm{H}-\mathrm{H}}=8.4,1 \mathrm{H}, \mathrm{CH} \mathrm{Ph}\right), 8.03\left(\mathrm{~d}, J_{\mathrm{H}-\mathrm{H}}=8.0\right.$, $1 \mathrm{H}, \mathrm{CH}$ qn), $7.88(\mathrm{~m}, 2 \mathrm{H}, \mathrm{CH}$ qn, $\mathrm{CH} \mathrm{Ph}), 7.73\left(\mathrm{t}, 1 \mathrm{H}, J_{\mathrm{H}-\mathrm{H}}=\right.$ 7.4, $\mathrm{CH}$ qn), $7.52\left(\mathrm{~d}, J_{\mathrm{H}-\mathrm{H}}=7.5,1 \mathrm{H}, \mathrm{CH}\right.$ qn), $7.37\left(\mathrm{dd}, J_{\mathrm{H}-\mathrm{H}}=\right.$ $\left.7.9, J_{\mathrm{H}-\mathrm{P}}=1.3,1 \mathrm{H}, \mathrm{CH} \mathrm{Ph}\right), 7.03\left(\mathrm{t}, J_{\mathrm{H}-\mathrm{H}}=7.6,1 \mathrm{H}, \mathrm{CH}\right.$ qn), $6.82\left(\mathrm{dt}, J_{\mathrm{H}-\mathrm{H}}=7.5, J_{\mathrm{H}-\mathrm{P}}=1.3,1 \mathrm{H} . \mathrm{CH} \mathrm{Ph}\right), 4.43\left(\mathrm{~s}, 2 \mathrm{H}, \mathrm{CH}_{2}\right)$, $1.52\left(\mathrm{~m}, 6 \mathrm{H}, \mathrm{PCH}\left(\mathrm{CH}_{3}\right)_{2} 0.91\left(\mathrm{dvt}, J_{\mathrm{H}-\mathrm{H}}=6.9, N=14.0,18 \mathrm{H}\right.\right.$, $\left.\mathrm{PCH}\left(\mathrm{CH}_{3}\right)_{2}\right), 0.80$ (dvt, $J_{\mathrm{H}-\mathrm{H}}=6.9, N=14.0,18 \mathrm{H}$, $\left.\mathrm{PCH}\left(\mathrm{CH}_{3}\right)_{2}\right),-2.78$ (br, $\left.2 \mathrm{H}, \mathrm{OsH}\right) .{ }^{1} \mathrm{H}\left\{{ }^{31} \mathrm{P}\right\}$ NMR (300 MHz, $\mathrm{CD}_{2} \mathrm{Cl}_{2}, 243 \mathrm{~K}$, high field region): $\delta-2.88$ ( $\mathrm{AB}$ spin system, $\left.J^{\text {calculated }}{ }_{\mathrm{A}-\mathrm{B}}=14731,2 \mathrm{H}, \mathrm{OsH}\right) . T_{1}(\mathrm{~min})(\mathrm{ms}, \mathrm{OsH}, 300 \mathrm{MHz}$, $\left.\mathrm{C}_{7} \mathrm{D}_{8}, 203 \mathrm{~K}\right): 46 \pm 4 .{ }^{31} \mathrm{P}\left\{{ }^{1} \mathrm{H}\right\} \mathrm{NMR}\left(121.5 \mathrm{MHz}, \mathrm{CD}_{2} \mathrm{Cl}_{2}, 298\right.$ $\mathrm{K}): \delta 16.2$ (s). ${ }^{13} \mathrm{C}\left\{{ }^{1} \mathrm{H}\right\}$-APT NMR, HMBC and HSQC (75.5 $\mathrm{MHz}, \mathrm{CD}_{2} \mathrm{Cl}_{2}, 298 \mathrm{~K}$ ): $\delta 298.6$ (s, OsCO), 168.6 (s, C qn), 167.8 (s, C PhO), 146.2 (s, C qn), 144.8 (s, CH qn), 140.6 (s, $\mathrm{CH} \mathrm{Ph}$ ), 134.3 (s, CH qn), 132.4 (s, CH Ph), 131.5 (s, C Ph), 130.7 (s, CH qn), 128.3 (s, CH qn), 128.2 (s, C qn), 125.8 (s, $\mathrm{CH} \mathrm{Ph}$ ), 123.9 (s, CH qn), 120.6 (s, CH qn), 113.8 (s, CH Ph), $65.5\left(\mathrm{~s}, \mathrm{CH}_{2}\right), 27.5$ (vt, $\left.N=27.1, \mathrm{PCH}\left(\mathrm{CH}_{3}\right)_{2}\right), 19.5$ (s, $\left.\mathrm{PCH}\left(\mathrm{CH}_{3}\right)_{2}\right), 19.0\left(\mathrm{~s}, \mathrm{PCH}\left(\mathrm{CH}_{3}\right)_{2}\right)$.

Computacional Details. All calculations were performed at the DFT level using the B3PW91 functional at vacuum as implemented in Gaussian09. ${ }^{40}$ The basis set used were Lanl2dz (Os) and 6-31G** for the rest of the atoms. For 2 we performed TD-DFT calculations at the same level of theory for the lowest 20 singlet-singlet and 20 singlet-triplet excitations at the ground state $\mathrm{S}_{0}$, and the lowest singlet-singlet and singlet-triplet excitations at the lowest excited triplet $\mathrm{T}_{1}$ optimized geometries. It has to be noticed that the singlet-triplet excitations are set to zero due to the neglect of spin-orbit coupling in the TD-DFT calculations as implemented in G09.

Structural Analysis of Complexes 2, 4 and 5. X-ray data were collected for the complexes on a Bruker Smart APEX CCD or DUO APEX CCD diffractometers equipped with a normal focus, $2.4 \mathrm{~kW}$ sealed tube source (Mo radiation, $1=$ $0.71073 \AA$ ) operating at $50 \mathrm{kV}$ and $40 \mathrm{~mA}$ (4) or $30 \mathrm{~mA}$ (2, and 5). Data were collected over the complete sphere. Each frame exposure time was $10 \mathrm{~s} \mathrm{(2,} \mathrm{and} \mathrm{5)} \mathrm{or} 30 \mathrm{~s} \mathrm{(4)} \mathrm{covering}$ $0.3^{\circ}$ in $\omega$. Data were corrected for absorption by using a multiscan method applied with the SADABS program. ${ }^{41}$ The structures were solved by Patterson or direct methods and refined by full-matrix least squares on $\mathrm{F}^{2}$ with SHELXL97, ${ }^{42}$ including isotropic and subsequently anisotropic displacement parameters. The hydrogen atoms (except hydrides) were observed in the least Fourier maps or calculated, and refined freely or using a restricted riding model. Hydrogens bonded to metal atoms were observed in the last cycles of refinement but refined too close to metals, so a restricted refinement model was used for all of them $(\mathrm{d}(\mathrm{Os}-\mathrm{H}=1.59(1) \AA)$.

Crystal data for 2: $\mathrm{C}_{31} \mathrm{H}_{53} \mathrm{NOOsP}_{2}, \mathrm{M}_{\mathrm{W}} 707.88$, orange, irregular block $\left(0.16 \times 0.12 \times 0.09 \mathrm{~mm}^{3}\right)$, monoclinic, space group $\mathrm{P} 2_{1} / \mathrm{n}, a: 16.9598(7) \AA, b: 10.7831(4) \AA, c: 17.8747(7) \AA, \beta$ : $107.1790(10)^{\circ}, V=3123.1(2) \AA^{3}, Z=4, Z^{\prime}=1, \mathrm{D}_{\text {calc }}: 1.506 \mathrm{~g}$ $\mathrm{cm}^{-3}, \mathrm{~F}(000): 1440, \mathrm{~T}=100(2) \mathrm{K}, \mu 4.209 \mathrm{~mm}^{-1} .28580$ measured reflections $\left(2 \theta: 3-58^{\circ}, \omega\right.$ scans $\left.0.3^{\circ}\right), 7511$ unique $\left(\mathrm{R}_{\text {int }}=\right.$ $0.0359)$; min./max. transm. factors $0.690 / 0.862$. Final agreement factors were $\mathrm{R}^{1}=0.0263$ (6658 observed reflections, I > $2 \mathrm{~s}(\mathrm{I}))$ and $\omega \mathrm{R}^{2}=0.0542 ;$ data/restraints/parameters 7511/3/346; GoF $=1.054$. Largest peak and hole 1.339 (close to osmium atoms) and $-0.869 \mathrm{e} / \AA^{3}$.

Crystal data for 4: $\mathrm{C}_{35} \mathrm{H}_{55} \mathrm{NOOsP}_{2}, \mathrm{M}_{\mathrm{W}} 757.94$, orange, irregu- lar block $\left(0.08 \times 0.03 \times 0.03 \mathrm{~mm}^{3}\right)$, monoclinic, space group $\mathrm{P} 2{ }_{1} / \mathrm{n}, a: 14.0888(10) \AA, b: 15.8579(11) \AA, c: 15.2962(10) \AA$, $\beta$ : 93.2240(10) $)^{\circ}, V=3412.0(4) \AA^{3}, Z=4, Z^{\prime}=1, \mathrm{D}_{\text {calc }}: 1.475 \mathrm{~g}$ $\mathrm{cm}^{-3}, \mathrm{~F}(000): 1544, \mathrm{~T}=100(2) \mathrm{K}, \mu 3.858 \mathrm{~mm}^{-1} .29571$ measured reflections $\left(2 \theta: 3-58^{\circ}\right.$, w scans $\left.0.3^{\circ}\right), 8112$ unique $\left(\mathrm{R}_{\text {int }}=\right.$ $0.0705)$; min./max. transm. Factors $0.681 / 0.862$. Final agreement factors were $\mathrm{R}^{1}=0.0486$ (6129 observed reflections, I > $2 \mathrm{~s}(\mathrm{I}))$ and $\omega \mathrm{R}^{2}=0.0858 ;$ data/restraints $/$ parameters $8112 / 2 / 382$; GoF $=1.072$. Largest peak and hole 1.823 (close to osmium atoms) and $-1.423 \mathrm{e} / \AA^{3}$.

Crystal data for 5: $\mathrm{C}_{31} \mathrm{H}_{54} \mathrm{NOOsP}_{2} \times \mathrm{BF}_{4} \times \mathrm{THF}, \mathrm{M}_{\mathrm{W}}$ 867.81, yellow, irregular block $\left(0.16 \times 0.06 \times 0.02 \mathrm{~mm}^{3}\right)$, monoclinic, space group $\mathrm{P} 21 / \mathrm{m}, a: 8.6959(12) \AA, b: 12.9629(17) \AA, c$ : $17.039(2) \AA, \beta: 104.647(2)^{\circ}, V=1858.3(4) \AA^{3}, Z=2, Z^{\prime}=0.5$, $\mathrm{D}_{\text {calc }}: 1.551 \mathrm{~g} \mathrm{~cm}^{-3}, \mathrm{~F}(000): 884, \mathrm{~T}=100(2) \mathrm{K}, \mu 3.569 \mathrm{~mm}^{-1}$. 19216 measured reflections $\left(2 \theta: 3-58^{\circ}, \omega\right.$ scans $\left.0.3^{\circ}\right), 5054$ unique $\left(\mathrm{R}_{\text {int }}=0.0433\right)$; min./max. transm. factors $0.685 / 0.842$. Final agreement factors were $\mathrm{R}^{1}=0.0312(4553$ observed reflections, $\mathrm{I}>2 \mathrm{~s}(\mathrm{I}))$ and $\omega \mathrm{R}^{2}=0.0763$; data/restraints/parameters 5054/7/240; GoF $=1.075$. Largest peak and hole 1.818 (close to osmium atoms) and $-0.983 \mathrm{e} / \AA^{3}$.

Photophysical studies. All the manipulations of the organometallic compound were carried out in strict absence of oxygen and water. UV-Vis spectra were recorded on an Evolution 600 spectrophotometer. Steady-state photoluminescence spectra were recorded in a Jobin-Yvon Horiba Fluorolog FL-3-11 spectrofluorometer. An IBH 5000F coaxial nanosecond flash lamp was used to measure the lifetimes.

\section{ASSOCIATED CONTENT}

Supporting Information. ${ }^{1} \mathrm{H},{ }^{13} \mathrm{C}\left\{{ }^{1} \mathrm{H}\right\}$, and the high-field region, as a function of the temperature, of the ${ }^{1} \mathrm{H}\left\{{ }^{31} \mathrm{P}\right\}$ NMR spectra of complexes 2-7, plots of $J_{\text {obs }}$ versus temperature for complexes 2 , $\mathbf{3}$, and 4, full reference 40; computational details; cartesian coordinates and xyz format file of optimized structures, and CIF files giving positional and displacement parameters, crystallographic data, and bond lengths and angles of compounds 2,4 , and $\mathbf{5}$. This material is available free of charge via the Internet at http://pubs.acs.org.

\section{AUTHOR INFORMATION}

\section{Corresponding Author}

*E-mail for M.A.E. maester@unizar.es

*E-mail for M.A.S sierraor@ucm.es

\section{Notes}

The authors declare no competing financial interests.

\section{ACKNOWLEDGMENT}

Financial support from the Spanish MINECO (Projects CTQ201346459-C2-01-P, CTQ2014-52799-P, and CTQ2014-51912-REDC the DGA (E35), and the European Social Fund (FSE) is acknowledged.

\section{REFERENCES}

(1) (a) Shilov, A. E.; Shul'pin, G. B. Chem. Rev. 1997, 97, 2879-2932. (b) Labinger, J. A.; Bercaw, J. E. Nature, 2002, 417 , 507-514. (c) Lersch, M.; Tilset, M. Chem. Rev. 2005, 105, 24712526. (d) Colby, D. A.; Bergman, R. G.; Ellman, J. A. Chem. Rev. 
2010, 110, 624-655. (e) Balcells, D.; Clot, E.; Eisenstein, O. Chem. Rev. 2010, 110, 749-823. (f) Mkhalid, I. A. I.; Barnard, J. H.; Marder, T. B.; Murphy, J. M.; Hartwig, J. F. Chem. Rev. 2010, 110, 890-931. (g) Kuhl, N.; Hopkinson, M. N.; Wencel-Delord, J.; Glorius, F. Angew. Chem. Int. Ed. 2012, 51, 10236-10254.

(2) (a) Tayebani, M.; Feghali, K.; Gambarotta, S.; Bensimon, C. Organometallics, 1997, 16, 5084-5088. (b) Cameron, T. M.; Abboud, K. A.; Boncella, J. M. Chem. Commun. 2001, 13, 1224-1225. (C) Ozerov, O. V.; Guo, C.; Fan, L.; Foxman, B. M. Organometallics, 2004, 23, 5573-5580. (d) Weng, W.; Guo, C.; Moura, C.; Yang, L.; Foxman, B. M.; Ozerov, O. V. Organometallics, 2005, 24, 3487-3499. (e) Surawatanawong, P.; Ozerov, O. V. Organometallics, 2011, 30, 2972-2979.

(3) Gray, S. D.; Weller, K. J.; Bruck, M. A.; Briggs, P. M.; Wigley, D. E. J. Am. Chem. Soc. 1995, 117, 10678-10693.

(4) (a) Zou, B.; Jiang, H.-F.; Wang, Z.-Y. Eur. J. Org. Chem. 2007, 27, 4600-4604. (b) Krüger, K.; Tillack, A.; Beller, M. ChemSusChem, 2009, 2, 715-717. (c) Zhao, X.; Liu, D.; Guo, H.; Liu, Y.; Zhang, W. J. Am. Chem. Soc. 2011, 133, 19354-19357. (d) Pan, Z.; Pound, S. M.; Rondla, N. R.; Douglas, C. J. Angew. Chem. Int. Ed. 2014, 53, 5170-5174. (e) Tobisu, M.; Nakamura, K.; Chatani, N. J. Am. Chem. Soc. 2014, 136, 5587-5590. (f) Chang, D.; Zhu, D.; Zuo, P.; Shi, L. Tetrahedron 2015, 71, 1684-1693.

(5) (a) Burling, S.; Mahon, M. F.; Powell, R. E.; Whittlesey, M. K.; Williams, J. M. J. J. Am. Chem. Soc. 2006, 128, 1370213703. (b) Wang, X.; Chen, H.; Li, X. Organometallics 2007, 26, 4684-4687. (c) Cabeza, J. A.; del Río, I.; Miguel, D.; SánchezVega, M. G. Angew. Chem. Int. Ed. 2008, 47, 1920-1922. (d) Häller, L. J. L.; Page, M- J.; Erhardt, S.; Mcgregor, S. A.; Mahon, M. F.; Naser, M. A.; Velez A.; Whittlesey, M. K. J. Am. Chem. Soc. 2010, 132, 18408-18416. (e) Arrowsmith, M.; Hill, M. S.; KociokKöhn, G.; MacDougall, D. J.; Mahon, M. F. Angew. Chem. Int. Ed. 2012, 51, 2098-2100.

(6) (a) Rybtchinski, B.; Milstein, D. Angew. Chem. Int. Ed. 1999, 38, 870-883. (b) Gandelman, M.; Shimon, L. J. W.; Milstein, D. Chem. Eur. J. 2003, 9, 4295-4300. (c) Gunay, A.; Jones, W. D.; J. Am. Chem. Soc. 2007, 129, 8729-8735. (d) Gunay, A.; Müller, C.; Lachicotte, R. J.; Brennessel, W. W.; Jones, W. D.; Organometallics 2009, 28, 6524-6530.

(7) Jun, C.-H. Chem. Soc. Rev. 2004, 33, 610-618.

(8) (a) Perthuisot, C.; Edelbach, B. L.; Zubris, D. L.; Jones, W. D. Organometallics 1997, 16, 2016-2023. (b) Edelbach, B. L.; Lachicotte, R. J.; Jones, W. D. J. Am. Chem. Soc. 1998, 120, 28432853. (c) Iverson, C. N.; Jones, W. D. Organometallics 2001, 20, 5745-5750. (d) Bart, S. C.; Chirik, P. J. J. Am. Chem. Soc. 2003, 125, 886-887. (e) Evans, M. E.; Li, T.; Jones, W. D. J. Am .Chem. Soc. 2010, 132, 16278-16284. (f) Castro-Rodrigo, R.; Esteruelas, M. A.; López, A. M.; López, F.; Mascareñas, J. L.; Oliván, M.; Oñate, E.; Saya, L.; Villarino, L. J. Am. Chem. Soc. 2010, 132, 454455.

(9) (a) Suggs, J. W.; Jun, C.-H. J. A. Chem. Soc. 1984, 106, 3054-3056. (b) Murakami, M; Amii, H.; Shigeto, K.; Ito, Y. J. Am. Chem. Soc. 1996, 118, 8285-8290. (c) Nishimura, T.; Uemura, S. J. Am. Chem. Soc. 1999, 121, 11010-11011. (d) Seiser, T.; Cramer, N. J. Am. Chem. Soc. 2010, 132, 5340-5341. (e) Grochowski, M. R.; Morris, J. Brennessel, W. W.; Jones, W. D. Organometallics 2011, 30, 5604-5610. (f) Huang, G.; Xia, Y. ACS Catal. 2015, 5, 859-868. (10) Crabtree, R. H.; Dion, R. P. J. Chem. Soc. Chem. Commun. 1984, 1260-1261. (b) Gauvin, R. M.; Rozenberg, H.; Shimon, L. J. W.; Ben-David, Y.; Milstein, D. Chem. Eur. J. 2007, 13, 13821393. (c) Anstey, M. R.; Yung, C. M.; Du, J.; Bergman, R. G. J. Am. Chem. Soc. 2007, 129, 776-777. (d) Kanda, H.; Kawashima, T.; Takao, T.; Suzuki, H. Organometallics 2012, 31, 1917-1926. (e) Masarwa, A.; Didier, D.; Zabrodski, T.; Schinkel, M.; Ackermann, L.; Marek, I. Nature 2014, 505, 199-203.

(11) (a) Barrio, P.; Castarlenas, R.; Esteruelas, M. A.; Oñate, E. Organometallics, 2001, 20, 2635-2638. (b) Baya, M.; Eguillor, B.; Esteruelas, M. A.; Lledós, A.; Oliván, M.; Oñate, E. Organometallics 2007, 26, 5140-5152 (c) Eguillor, B.; Esteruelas, M. A.; Oliván, M.; Puerta, M. Organometallics 2008, 27, 445-450. (d). Esteruelas, M. A.; Fernández, I.; Herrera, A.; Martín-Ortiz M.; Martí-
nez-Álvarez, R.; Oliván, M.; Oñate, E.; Sierra, M. A.; Valencia, M. Organometallics 2010, 29, 976-986. (e) Eguillor, B.; Esteruelas, M. A.; García-Raboso, J.; Oliván, M.; Oñate, E.; Pastor, I. M.; Peñafiel, I.; Yus, M. Organometallics 2011, 30, 1658-1667. (f) Crespo, O.; Eguillor, B.; Esteruelas, M. A.; Fernández, I.; Garcia-Raboso, J.; Gómez-Gallego, M.; Martín-Ortiz, M.; Oliván, M.; Sierra, M. A. Chem. Commun. 2012, 48, 5328-5330. (g) Bolaño, T.; Esteruelas, M. A.; Fernández, I.; Oñate, E.; Palacios, A.; Tsai, J.-T.; Xia, C. Organometallics 2015, 34, 778-779.

(12) (a) Esteruelas, M. A.; Lahoz, F. J.; López, A. M.; Oñate, E.; Oro, L. A.; Ruiz, N.; Sola, E.; Tolosa, J. I. Inorg. Chem. 1996, 35, 7811-7817. (b) Esteruelas, M. A.; García-Raboso, J.; Oliván, M. Organometallics 2011, 30, 3844-3852. (c) Esteruelas, M. A.; García-Raboso, J.; Oliván, M. Inorg. Chem. 2012, 51, 9522-9528.

(13) Esteruelas, M. A.; García-Raboso, J.; Oliván, M.; Oñate, E. Inorg. Chem. 2012, 51, 5975-5984.

(14) Casarrubios, L.; Esteruelas, M. A., Larramona, C.; Muntaner, J. G.; Oliván, M., Oñate, E.; Sierra, M. A. Organometallics, 2014, 33, 1820-1833.

(15)<smiles>[R3][C]1[C]([Y7])N([R1])C1=O</smiles>

(16) Two types of concerted or sequential breakage of parallel $\mathrm{N}-\mathrm{C}$ and $\mathrm{C}-\mathrm{C}$ bonds have been described. That involving N1-C2 and C3-C4 (A) gives a ketene and an imine. (See: (a) Fischer, M. Chem. Ber. 1968, 101, 2669-2678. (b) Pérez-Ruiz, R.; Saéz, J. A.; Domingo, L. R.; Jiménez, M. C.; Miranda, M. A. Org. Biomol. Chem. 2012, 10, 7928-7932.) whereas that involving N1-C4 and C2-C3 (B) leads to an olefin and an isocyanate. (See: (c) Paquette, L. A.; Wyvratt, M. J.; Allen, Jr. G. R. J. Am. Chem. Soc. 1970, 92, 1763-1765. (d) Banfi, L.; Beretta, M. G.; Colombo, L.; Gennari, C.; Scolastico, C. J. Chem. Soc., Chem. Commun. 1982, 488-490. (e) Alcaide, B.; Miranda, M.; Pérez-Castells, J.; Sierra, M. A. J. Org. Chem. 1993, 58, 297-298. (f) Alcaide, B.; Pérez-Castells, J.; Polanco, C.; Sierra, M. A. J. Org. Chem. 1995, 60, 6012-6016. (e) Ardura, D.; Sordo, T. L. J. Phys. Chem. A. 2003, 107, 10171-10176). (17) Casarrubios, L.; Esteruelas, M. A.; Larramona, C.; Lledós, A.; Muntaner, J. G.; Oñate, E.; Ortuño, M. A.; Sierra, M. A. Chem. Eur. J. 2015, in press.

(18) Jones, W. D.; Feher, F. J. Acc. Chem. Rev. 1989, 22, 91-

(19) (a) Selander, N.; Szabò, K. J. Chem. Rev. 2011, 111, 2048 2076. (b) Younus, H. A.; Ahmad, N.; Su, W.; Verpoort, F. Coor. Chem. Rev. 2014, 276, 112-152.

(20) (a) Albrecht, M.; van Koten, G. Angew. Chem. Int. Ed. 2001, 40, 3750-3781. (b) Choi, J.; MacArthur, A. H. R.; Brookhart, M.; Goldman, A. Chem. Rev. 2011, 111, 1761-1779. (c) Gunanathan, C.; Milstein, D. Chem. Rev. 2014, 114, 12024-12087.

(21) (a) Albrecht, M.; Rodríguez, G.; Schoenmaker, J.; van Koten, G. Org. Let. 2000, 2, 3461-3464. (b) Ni, W.-X.; Man, W.-L.; Cheung, M. T.-W.; Sun, R. W.-Y.; Shu, Y.-L.; Lam, Y.-W.; Che, C.-M.; Lau, T.-C. Chem. Commun. 2011, 47, 2140-2142. (c) Boff, B.; Gaiddon, C.; Pfeffer, M. Inorg. Chem. 2013, 52, 2705-2715. (d) Menéndez-Pedregal, E.; Manteca, A.; Sánchez, J.; Díez, J.; Gamasa, M. P.; Lastra, E. Eur. J. Inorg. Chem. 2015, 1424-1432.

(22) (a) Chung, L.-H.; Chan, S.-C.; Lee, W.-C.; Wong, C.-Y Inorg. Chem. 2012, 51, 8693-8703. (b) Alabau, R. G.; Eguillor, B.; Esler, J.; Esteruelas, M. A.; Oliván, M.; Oñate, E.; Tsai, J.-Y.; Xia, C. Organometallics 2014, 33, 5582-5596.

(23) (a) Maestri, A. G.; Taylor, S. D.; Schuck, S. M.; Brown, S. N. Organometallics 2004, 23, 1932-1946. (b) Castarlenas, R.; Esteruelas, M. A.; Oñate, E. Organometallics 2007, 26, 3082-3084. (c) Esteruelas, M. A.; Masamunt, A. B.; Oliván, M.; Oñate, E.; Valencia, M. J. Am. Chem. Soc. 2008, 130, 11612-11613. (d) Asensio, G.; Cuenca, A. B.; Esteruelas, M. A.; Medio-Simón, M.; Oliván, M.; 
Valencia, M. Inorg. Chem. 2010, 49, 8665-8667. (e) Esteruelas, M. A.; Honczek, N.; Oliván, M.; Oñate, E.; Valencia, M. Organometallics 2011, 30, 2468-2471. (f) Spasyuk, D.; Smith, S.; Gusev, D. G. Angew. Chem. Int. Ed. 2012, 51, 2772-2775. (g) Alós, J.; Bolaño, T.; Esteruelas, M. A.; Oliván, M.; Oñate, E.; Valencia, M. Inorg. Chem. 2013, 52, 6199-6213. (h) Shao, J.-Y.; Zhong, Y.-W. Inorg. Chem. 2013, 52, 6464-6472. (i) Vega, E.; Lastra, E.; Gamasa, M. P. Inorg. Chem. 2013, 52, 6193-6198. (j) Chung, L.-H.; Cho, K.-S.; England, J.; Chan, S.-C.; Wieghardt, K.; Wong, C.-Y. Inorg. Chem. 2013, 52, 9885-9896. (k) Alós, J.; Bolaño, T.; Esteruelas, M. A.; Oliván, M.; Oñate, E. Inorg. Chem. 2014, 53, 1195-1209. (1) Spasyuk, D.; Vicent, C.; Gusev, D. G. J. Am. Chem. Soc. 2015, 137, 3743-3746

(24) (a) Santra, B. K.; Munshi, P.; Das, G.; Bharadwaj, P.; Lahiri, G. K. Polyhedron 1999, 18, 617-630. (b) Betley, T. A.; Qian, B. A.; Peters, J. C. Inorg. Chem. 2008, 47, 11570-11582. (c) Chen, J.-L.; Chi, Y.; Chen, K.; Cheng, Y.-M.; Chung, M.-W.; Yu, Y.-C.; Lee, G.-H.; Chou, P.-T.; Shu, C.-F. Inorg. Chem. 2010, 49, 823832. (d) Chelucci, G.; Baldino, S.; Baratta, W. Acc. Chem. Res. 2015, 48, 363-379. (e) Müller, A. L.; Wadepohl, H.; Gade, H. L; Organometellics 2015, 34, 2810-2818.

(25) (a) Lee, J.-H.; Pink, M.; Caulton, K. G. Organometallics 2006, 25, 802-804. (b) Wen, T. B.; Zhou, Z. Y.; Jia, G. Angew. Chem. Int. Ed. 2006, 45, 5842-5846. (c) Kuznetsov, V. F.; Gusev, D. G. Organometallics 2007, 26, 5661-5666. (d) Tsvetkov, N.; Fan, H.; Caulton, K. G. Dalton Trans. 2011, 40, 1105-1110. (e) Gruver, B. C.; Adams, J. J.; Arulsamy, N.; Roddick, D. M. Organometallics 2013, 32, 6468-6475.

(26) (a) Gupta, P.; Butcher, R. J.; Bhattacharya, S. Inorg. Chem. 2003, 42, 5405-5411. (b) Acharyya, R.; Peng, S.-M.; Lee, G.-H.; Bhattacharya, S. Inorg. Chem. 2003, 42, 7378-7380.

(27) (a) Li, Z.-Y.; Yu, W.-Y.; Che, C.-M.; Poon, C.-K.; Wang, R.-J.; Mak, T. C. W. J. Chem. Soc., Dalton Trans. 1992, $1657-$ 1661. (b) Xiang, J.; Man, W.-L.; Yiu, S.-M.; Peng, S.-M.; Lau, T.C. Chem. Eur. J. 2011, 17, 13044-13051.

(28) See for example: (a) Esteruelas, M. A.; Gutierrez-Puebla, E.; López, A. M.; Oñate, E.; Tolosa, J. I. Organometallics 2000, 19, 275-284. (b) Baya, M.; Esteruelas, M. A.; Oñate, E. Organometallics 2001, 20, 4875-4886. (c) Esteruelas, M. A.; Hernández, Y. A.; López, A.; M.; Oliván, M, Oñate, E. Organometallics 2005, 24, 5989-6000. (d) Cerón-Camacho, R.; Morales-Morales, D.; Hernández, S.; Le Lagadec, R.; Ryabov, A. D. Inorg. Chem. 2008, 47, 4988-4995.

(29) Barrio, P.; Esteruelas, M. A.; Oñate, E. Organometallics 2004, 23, 3627-3639.
(30) (a) Esteruelas, M. A.; Fernández, I.; Fuertes, S.; López, A M.; Oñate, E.; Sierra, M. A. Organometallics 2009, 28, 4876-4879. (b) Castro-Rodrigo, R.; Esteruelas, M. A.; Fuertes, S.; López, A. M.; Mozo, S.; Oñate, E. Organometallics 2009, 28, 5941-5951.

(31) Batuecas, M.; Esteruelas, M. A.; García-Yebra, C.; Oñate, E. Organometallics 2012, 31, 8079-8081, and references therein.

(32) Sabo-Etienne, S.; Chaudret, B. Chem. Rev. 1998, 98, 2077 2091.

(33) (a) Jarid, A.; Moreno, M.; Lledós, A.; Lluch, J. M.; Bertrán, J. J Am. Chem. Soc. 1995, 117, 1069-1075. (b) Jones, A. L.; McGray, G. S.; Sirsch, P.; Steed, J. W. Chem. Commun. 2005, 48, 5994-5996.

(34) Zilm, K. W.; Heinekey, D. M.; Millar, J. M. Payne, N. G.; Neshyba, S. P.; Duchamp, J. C.; Szczyrba, J. J. Am. Chem. Soc. 1990, 112, 920-929.

(35) Heinekey, D. M.; Hinkle, A. S.; Close, J. D. J. Am. Chem. Soc. 1996, 118, 5353-5361.

(36) (a) Castillo, A.; Esteruelas, M. A.; Oñate, E.; Ruiz, N. J. Am. Chem. Soc. 1997, 119, 9691-9698. (b) Castillo, A.; Barea, G.; Esteruelas, M. A.; Lahoz, F. J; Lledós, A.; Maseras, F.; Modrego J.; Oñate, E.; Oro, L. A.; Ruiz, N.; Sola, E. Inorg. Chem. 1999, 38, 1814-1824.

(37) Bautista, M. T.; Cappellani, E. P.; Drouin, S. D.; Morris, R. H.; Schweitzer, C. T.; Sella, A.; Zubkowski, J. J. Am. Chem. Soc. 1991, 113, 4876-4887.

(38) See for example: (a) Ojima, I. Acc. Chem. Res. 1995, 28, 383-389. (b) Ojima, I.; Delaloge, F. Chem. Soc. Rev. 1997, 26, $377-$ 386. (c) Angelaud, R.; Zhong, Y. L.; Maligres, P.; Lee, J.; Askin, D. J. Org. Chem. 2005, 70, 1949-1952. (d) Kiss, L.; Forró, E.; Fustero, S.; Fülöp, F. Org. Biomol. Chem. 2011, 9, 6528-6534. (e) Kamath, A.; Ojima, I. Tetrahedrom 2012, 68, 10640-10664. (f) Kiss, L.; Forrò, E.; Fülöp, F. Tetrahedron 2012, 68, 4438-4443.

(39) Aracama, M.; Esteruelas, M. A.; Lahoz, F. J.; López, J. A.; Meyer, U.; Oro, L. A.; Werner, H. Inorg. Chem. 1991, 30, 288-293. (40) Frisch, M. J. et al Gaussian09 (Rev. D.01); Gaussian, Inc. Wallingford CT, 2009.

(41) Blessing, R. H. Acta Crystallogr., Sect. A: Found. Crystal$\log$. 1995, A51, 33-38. SADABS: Area-detector absorption correction; Bruker- AXS, Madison, WI, 1996.

(42) SHELXTL Package v. 6.14; Bruker-AXS, Madison, WI, 2000. Sheldrick, G. M. Acta Cryst., Sect. A: Found. Crystallogr. 2008, A64, 112-122. 
2-Azetidinones as Precursors of Pincer Ligands: Preparation, Structure, and Spectroscopic Properties of $\mathrm{CC}^{\prime} \mathrm{N}$-Osmium Complexes

$\beta$-lactams should be taken into account in coordination chemistry because their metal-mediated productive degradation leads to novel pincer ligands, which allow to stabilize transition metal complexes with interesting spectroscopic properties.

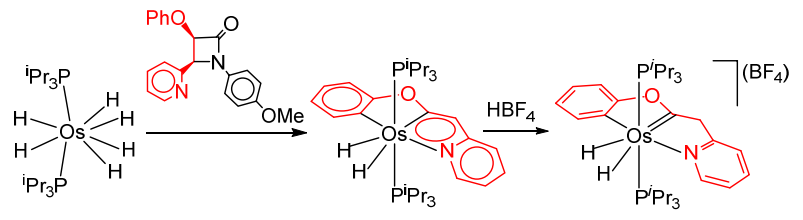

